\title{
The European crisis: Analysis of the macroeconomic imbalances in the rescued euro area countries
}

\author{
Leonida Correia \\ Centre for Transdisciplinary Development Studies, \\ University of Trás-os-Montes and Alto Douro, \\ Portugal \\ lcorreia@utad.pt

\section{Patrícia Martins} \\ Centre for Transdisciplinary Development Studies, \\ University of Trás-os-Montes and Alto Douro, \\ Portugal \\ smartins@utad.pt
}

Abstract. Macroeconomic imbalances are considered as one of the most important causes of European crisis. The crisis has significantly aggravated these imbalances, and some euro area countries - Greece, Ireland, Portugal, Spain and Cyprus - have had to request economic and/or financial assistance. Using the scoreboard of headline indicators of the Macroeconomic Imbalance Procedure as reference and applying statistical analysis methods, this paper provides new evidence on the role played by the assistance programmes in these five rescued countries and analyses their patterns of divergence/convergence relative to the

Received: December, 2018 1st Revision:

February, 2019

Accepted:

May, 2019

DOI

$10.14254 / 2071$ $8330.2019 / 12-2 / 2$ euro area aggregate since 2007. The evidence indicates that the values of the net international investment position, private and public debt and the unemployment rates have diverged considerably from the thresholds and the euro area averages. A decade after the start of European crisis, although the economic situation has improved, the effects of the crisis and of the austerity policies continue to be felt and the macroeconomic imbalances persist in the rescued countries.

Keywords: Macroeconomic imbalances, financial assistance, European crisis, rescued countries.

JEL Classification: E62, E65, F15, F45

\section{INTRODUCTION}

The most recent financial crisis began in 2007 in the United States (US) with the subprime mortgage crisis, and quickly spread to the European Union (EU). It is considered the broadest, longest and deepest recession since the Great Depression of the 1930s. This recession hit hard almost all the countries in the world: they experienced sharp declines in economic growth, and there was a particularly negative and 
prolonged impact in Europe. In 2009, the real gross domestic product (GDP) of the countries in the euro area (EA) and the EU as whole experienced the sharpest contraction in history (at around 4.5\%) (Fig. 1).

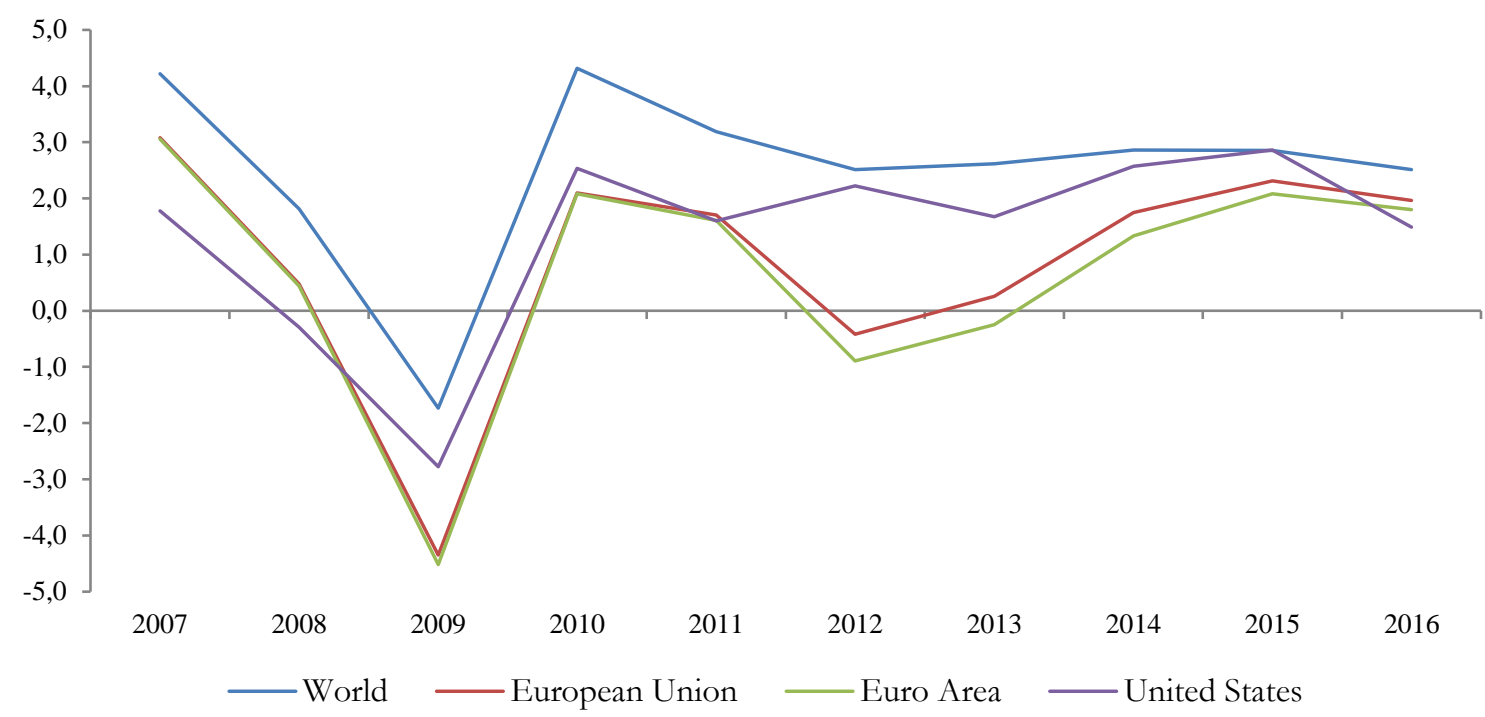

Figure 1. GDP growth rate in the World, Europe and the United States, 2007-2017 (in \%)

Source: World Bank Database (databank.worldbank.org)

Literature has extensively discussed the underlying causes of this financial crisis (European Commission, 2009; Claessens et al., 2010; Kenc \& Dibooglu, 2010; Zestos, 2016; Howarth \& Quaglia, 2016). In general, they can be summarized as excessive international macroeconomic imbalances, very expansive monetary and fiscal policies (especially in the US) and poor financial regulation.

Another strand of literature has analysed how the financial crisis spread around Europe and why it has lasted so long. Several authors (Gibson et al., 2014; Moro, 2014; Zestos, 2016) have addressed the topics related to the economic and European sovereign debt crisis, including their theoretical and empirical explanations, the policy options for dealing with the related problems and also lessons for the future. Overall, there seems to be a consensual conclusion that the European countries were affected to different degrees depending on their economic structure and vulnerability to shocks and that the peripheral countries have become the most vulnerable to the vicissitudes of the crisis (Correia, 2016).

Macroeconomic imbalances (external and internal ones) are considered as one of the most important causes of the economic and sovereign debt crisis in Europe. Kamps et al. (2014) identified two key factors contributing to the successive build-up of macroeconomic imbalances in several EA countries: low real financing costs and overly optimistic assumptions of private and public sectors about future economic developments. Both factors led to a significant cumulative deterioration in competitiveness and, thus, current account deficits and external debt burdens increased significantly in some economies. Notwithstanding, the excessive current account surplus is also a problem of external imbalance (WadjaLichy, 2015).

The crisis has significantly aggravated the imbalances, and some EA countries - Greece (in 2010), Ireland (in 2010), Portugal (in 2011), Spain (in 2012) and Cyprus (in 2013) - had to request international financial support. To benefit from economic and financial assistance from the EU and the International Monetary Fund (IMF), these five countries became subjects to macroeconomic adjustment programmes, with surveillance of their imbalances and monitoring of corrective measures taking place in the context of these programmes. In Spain, a financial assistance programme for recapitalization of financial institutions was implemented.

Our paper contributes to the literature that explores the European crisis effects, providing new evidence on the impact of the Great Recession and the role played by the assistance programmes in the 
five rescued EA countries (Cyprus, Greece, Ireland, Portugal and Spain). Specifically, the main objectives of the paper are threefold: (i) to analyse the effects of the recent crisis and the impact of the assistance programmes in the rescued countries; (ii) to examine the evolution of the macroeconomic situation in each of these countries, exploring the patterns of divergence/convergence relative to the EA aggregate; and (iii) to identify the main lessons from the crisis for economic policy.

To analyse the evolution of the economic situation within EA countries, with particular attention to the five countries that received financial and/or macroeconomic assistance, we use the scoreboard of 14 headline indicators and the indicative thresholds from the Macroeconomic Imbalance Procedure (MIP).

The remainder of the paper is organized as follows. Section 2 reviews the economic and/or financial assistance programmes. Section 3 analyses the creation of the MIP and its implementation. Section 4 provides an evaluation of the impact of those programmes on the rescued countries and of the patterns of divergence/convergence relative to the EA aggregate. Section 5 discusses the implications and the lessons for economic policy. The concluding remarks are presented in Section 6.

\section{ASSISTANCE PROGRAMMES}

The global crisis has exposed important structural and institutional weaknesses in EA namely the inefficiency of the Stability and Growth Pact (SGP). Before the sovereign debt crisis, de Grauwe (2007: 185) stated: "The only reason why we need a Pact is to avoid that countries get into a debt crisis". However, the SGP has not been able to achieve the objectives behind its creation: fiscal sustainability and macroeconomic stabilization.

The fiscal rules of the SGP have been violated by several countries for a long time and led to a substantial increase in the public debt. In 2007, prior to the crisis spreading to Europe, eight EA countries (Austria, Belgium, France, Germany, Greece, Italy, Malta and Portugal) exceeded the $60 \%$ ratio of government debt (Table A.1, in the Appendix).

At the fiscal policy level, the European Commission (EC) took two contradictory roles: on the one hand, it encouraged national governments to implement expansionary discretionary fiscal policies that worsened the public finance situation of their respective countries and, on the other, triggered the introduction of excessive deficit procedures.

The crisis has also exacerbated the countries' macroeconomic imbalances, which together with other unfavourable external factors (such as the strong increase in sovereign debt spreads and the difficulty of some domestic banks to access external credit) have left countries vulnerable to financial market volatility. At the beginning of the crisis, EU country leaders did not demonstrate to the financial markets that they were committed to defending the euro and EA and were unable to deal with the crisis.

Delays in monetary policy decisions have also contributed to the depth of the euro crisis. In reaction to the crisis, the ECB took some time to react and only later implemented non-conventional monetary policy. The monetary policy after the onset of the crisis was in general contractionary and slow to respond to the deterioration of the economic situation.

In early 2010, when the alarm sounded due to Greece's financing difficulties, the EA sovereign debt markets showed they did not have the means to address and solve such situation. Based on the principles of "no default, no bailout and no exit", Europe failed doubly in crisis prevention and its resolution. As a result, the markets became frightened and began to demand much higher risk premiums from the most over-indebted countries.

In Greece, Ireland and Portugal, the long-term interest rates on government bonds increased so much that it became prohibitively expensive to finance their debts on the financial markets and they had to request economic and financial assistance from the EU and IMF, in 2010 the first two countries and in 2011 the last one. Spain and Cyprus joined to the group of the rescued countries in 2012 and 2013, respectively. 
Figure 2 shows the rapid evolution of public debt ratios of the rescued countries after 2007. At the time they requested bailout, these countries had the following public debt ratios: Greece (EL) - 146.2\%; Ireland (IE) - 86.1\%; Portugal (PT) - 111.4\%; Spain (ES) - 85.7\% and Cyprus (CY) - 102.6\%.

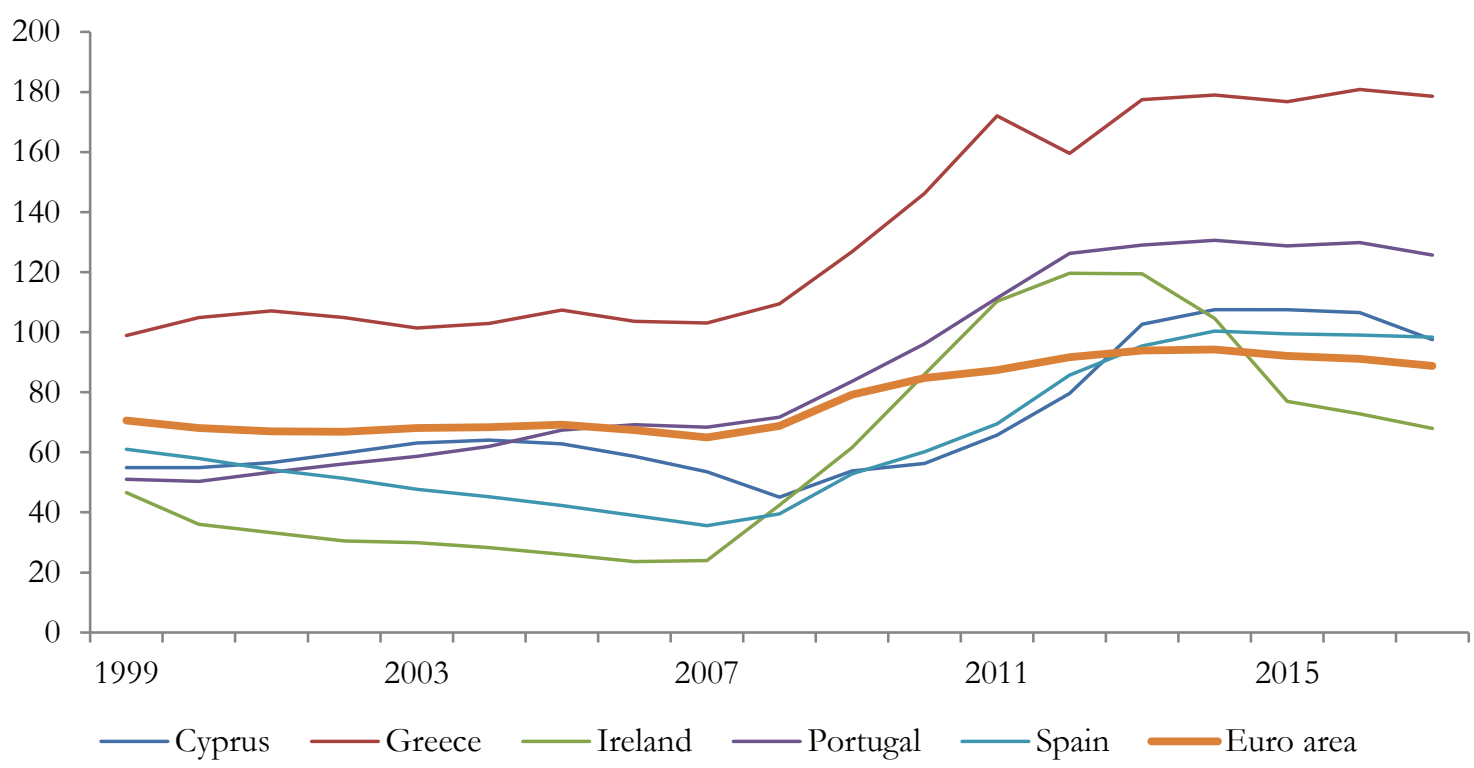

Figure 2. Ratio government gross debt/GDP in rescued countries and EA, 1999-2017 (\%) Source: Data from AMECO (ec.europa.eu/economy_finance/ameco)

To provide assistance to the countries threatened by financing difficulties, specific mechanisms are created by EU. In 2010, the European Financial Stability Facility (EFSF) was established as a rescue fund for the 2010-2013 period, as a temporary crisis resolution mechanism for EA countries to prevent the crisis from spreading and deepening. After 2011, the EA countries could request assistance from the European Stability Mechanism (ESM), a permanent crisis resolution mechanism that replaced the EFSF, and from the European Financial Stabilization Mechanism (EFSM). EU countries are also eligible to seek financial assistance from the International Monetary Fund (IMF). A succinct characterization (amount, date of agreement, financing and period) of the assistance programmes for Greece, Ireland, Portugal, Spain and Cyprus is presented in Table 1.

Table 1

The assistance programmes of Greece, Ireland, Portugal, Spain and Cyprus

\begin{tabular}{|l|c|c|c|c|c|}
\hline \multicolumn{2}{|c|}{ Country } & Amount & Agreement Date & Financing & Period \\
\hline \multirow{2}{*}{ Greece } & $1^{\text {st }}$ bailout & $€ 110$ billion & May 2010 & $\begin{array}{c}\text { EA countries: } € 80 \text { billion } \\
\text { IMF: } € 30 \text { billion }\end{array}$ & $2010-2013$ \\
\cline { 2 - 6 } & $2^{\text {nd }}$ bailout & $€ 130$ billion & March 2012 & $\begin{array}{c}\text { EFSF: } € 102 \text { billion } \\
\text { IMF: } € 28 \text { billion }\end{array}$ & $2012-2014$ \\
\cline { 2 - 6 } & $3^{\text {rd }}$ bailout & $€ 86$ billion & August 2015 & ESM: $€ 86$ billion & $2015-2018$ \\
\hline \multirow{2}{*}{ Ireland } & \multirow{2}{*}{$\begin{array}{l}\text { EF billion } \\
\text { Portugal }\end{array}$} & December 2010 & $\begin{array}{c}\text { EFSM: } € 22.5 \text { billion } \\
\text { IMF: } € 22.5 \text { billion } \\
\text { Ireland: } € 17.5 \text { billion }\end{array}$ & $2010-2013$ \\
\hline Spain & $€ 78$ billion & May 2011 & $\begin{array}{c}\text { EFSF: } € 26 \text { billion } \\
\text { EFSM: } € 26 \text { billion } \\
\text { IMF: } € 26 \text { billion }\end{array}$ & $2011-2014$ \\
\hline Cyprus & $€ 100$ billion & July 2012 & ESM: $€ 100$ billion & $2012-2014$ \\
\hline
\end{tabular}

Source: Adapted from European Commission site (ec.europa.eu) 
In return for the loans received, Greece, Ireland, Portugal and Cyprus had to comply with austerity packages, having to implement policies designed with the objective to address the underlying economic problems. The idea was that the bailouts would protect each country from bankruptcy and also free the ECB from having to provide additional liquidity to these countries, thus avoiding the risk of creating inflation (Zestos, 2016). The austerity programmes include reduction in government expenditure, increase in taxes, privatization programmes and reduction in private and public wages and pensions.

Ireland, Portugal and Cyprus have successfully completed the EU-IMF assistance programmes in December of 2013, May of 2014 and March 2016, respectively, and Spain has also successfully exited the EU financial assistance programme for the recapitalization of financial institutions in January 2014. These countries are subject to a Post-Programme Surveillance (PPS), with the objective to measure the countries' capacity to repay their outstanding loans. In August 2018, after 8 years of external intervention and three assistance programmes, Greece left the assistance programme, and joins Ireland, Spain, Cyprus and Portugal in the PPS. This marks the end of the cycle of bailouts in EA within the context of the recent crisis.

Several authors (Zestos, 2016; Stiglitz, 2016) have severely criticized the assistance programmes, saying that they are badly designed and not adjusted to the reality of the bailout recipient countries, which experienced dramatic effects in terms of decreases in economic growth and employment, and increases in unemployment and political instability. Moreover, they consider that the Troika's policies aggravated the already deficient structure of the EA, amplifying its weaknesses and imperfections. The recent development of extremist political parties, scepticism about the process of European integration, the situations of Catalonia and Brexit are given as proof of the negative social and political consequences of the bailout programmes.

\section{MACROECONOMIC IMBALANCE PROCEDURE}

Concerned about the future of the EA, reform of the macroeconomic governance was inevitable. In the aftermath of the crisis, several institutional changes were introduced. In 2011, a collection of six new laws, known as the "six-pack", made the SGP more comprehensive and easier to enforce and introduced the MIP (Regulation EU No 1176/2011). The MIP "intends to identify trends that, if left unaddressed, would imply a sudden and possibly disorderly correction due to an accumulation of macro-financial risks" (European Commission, 2015: 3). Thus, the main rationale of the MIP is preserving macroeconomic stability, bearing in mind that macroeconomic imbalances in one country could spill over and threaten others. Its effective implementation is one of the priorities of the EC.

The MIP forms part of the European Semester and thus follows a regular cycle. The Alert Mechanism Report (AMR), usually published in November of year t-1, signals countries with potential imbalances or whose situation warrants particular attention. The selected countries in AMR are analysed in in-depth-reviews (IDRs) by the EC to assess the existence of imbalances and to evaluate their severity. In the spring of the year $t$, IDRs are published and may result in the identification of "no imbalances", "imbalances", "excessive imbalances" and "excessive imbalances with corrective action". The last category implies the introduction of the Excessive Imbalance Procedure (EIP), but this procedure has, so far, not been launched for any countries identified as having excessive imbalances. The countries identified as having imbalances or excessive imbalances will receive country-specific recommendations issued by the EC in May.

The analysis in the AMR is based on a scoreboard of 14 headline indicators and complemented by 25 axiliary indicators and by all available and relevant information. ${ }^{1}$ The headline indicators, listed in Table 2,

${ }^{1}$ The initial scoreboard included 10 headline indicators (for a detailed description of these indicators, see European Commission, 2012). An eleventh headline indicator on the financial sector was added in 2012 . Three employment variables, previously auxiliary 
are divided into three main areas: external imbalances and competitiveness, internal imbalances and employment indicators.

Table 2

Scoreboard indicators and thresholds

\begin{tabular}{|c|c|c|c|c|c|}
\hline Main areas & Indicators & Measure & $\begin{array}{l}\text { Types } \\
\text { of } \\
\text { variable }\end{array}$ & $\begin{array}{l}\text { Upper } \\
\text { threshold }\end{array}$ & $\begin{array}{l}\text { Lower } \\
\text { threshold }\end{array}$ \\
\hline \multirow{5}{*}{$\begin{array}{c}\text { External } \\
\text { imbalances and } \\
\text { competitiveness }\end{array}$} & Current account balance & $\%$ of GDP, 3-year average & Flow & $6 \%$ & $-4 \%$ \\
\hline & $\begin{array}{l}\text { Net international investment } \\
\text { position }\end{array}$ & $\%$ of GDP & Stock & & $-35 \%$ \\
\hline & Real effective exchange rate & $\begin{array}{l}42 \text { trading countries, HICP } \\
\text { deflator, } 3 \text {-year } \% \text { change }\end{array}$ & Flow & $\begin{array}{l}5 \%(\mathrm{EA}) / \\
11 \% \text { (Non- } \\
\text { EA) }\end{array}$ & $\begin{array}{l}-5 \%(\mathrm{EA}) / \\
-11 \% \text { (Non- } \\
\text { EA) }\end{array}$ \\
\hline & Export market share & $\begin{array}{c}\% \text { of world exports, } 5 \text {-year } \% \\
\text { change }\end{array}$ & Flow & & $-6 \%$ \\
\hline & Nominal unit labour cost index & $2010=100,3$-year $\%$ change & Flow & $\begin{array}{l}9 \%(\mathrm{EA}) / \\
12 \% \text { (Non- } \\
\text { EA) }\end{array}$ & \\
\hline \multirow{6}{*}{$\begin{array}{l}\text { Internal } \\
\text { imbalances }\end{array}$} & House price index, deflated & $2015=100,1$-year $\%$ change & Stock & $6 \%$ & \\
\hline & $\begin{array}{l}\text { Private sector credit flow, } \\
\text { consolidated }\end{array}$ & $\%$ of GDP & Stock & $14 \%$ & \\
\hline & Private sector debt, consolidated & $\%$ of GDP & Stock & $133 \%$ & \\
\hline & $\begin{array}{l}\text { General government gross debt, } \\
\text { excessive deficit procedure } \\
\text { concept }\end{array}$ & $\%$ of GDP & Stock & $60 \%$ & \\
\hline & Unemployment rate & 3-year average & Flow & $10 \%$ & \\
\hline & $\begin{array}{l}\text { Total financial sector liabilities, } \\
\text { non-consolidated }\end{array}$ & 1 -year $\%$ change & Stock & $16.5 \%$ & \\
\hline \multirow{3}{*}{$\begin{array}{l}\text { Employment } \\
\text { indicators }\end{array}$} & Activity rate & $\begin{array}{c}\% \text { of total population aged } 15- \\
64,3 \text {-year change in p.p. }\end{array}$ & Flow & & -0.2 p.p. \\
\hline & Long-term unemployment rate & $\begin{array}{l}\% \text { of active population aged } \\
15-74,3 \text {-year change in p.p. }\end{array}$ & Flow & 0.5 p.p. & \\
\hline & Youth unemployment rate & $\begin{array}{l}\% \text { of active population aged } \\
15-24,3 \text {-year change in p.p. }\end{array}$ & Flow & 2 p.p. & \\
\hline
\end{tabular}

Source: Adapted from European Commission (2016)

There are six stock variables that are static estimates referring to the year $t-2$, usually the most recent available year, and the other indicators are flow variables, which are either transformed into 3-year moving averages or percentage changes over a 3-year or 5-year window. For each headline indicator, there is a respective alert level. In some variables there are upper and lower thresholds simultaneously and sometimes the thresholds are tighter in EA countries than in non-EA countries.

The MIP takes an integrated and forward-looking approach to macroeconomic surveillance. The AMR analysis goes beyond the reading of the scoreboard and the assessment of the headline indicators is non-mechanistic. The "economic reading" of the scoreboard is essential as the nature of the imbalances can be very different throughout EU Member States. For the identification of macro-financial risks, not only does the number of variables hitting alert levels matter but also the existence of specific configurations, such as large and growing stock imbalances, interlinked stock imbalances and stock imbalances underpinned by trends in the real economy (European Commission, 2016). For example, Kamps et al. (2014) stress that, in 2013, the EC considered that imbalances were "excessive" in Slovenia although only two indicators had breached the respective threshold.

All EU Member States are analysed in AMR, except those countries that are the subject of EU-IMF programmes, given that they are already under enhanced macroeconomic surveillance as part of these 
programmes. As presented in Table 3, this means that in the case of Ireland and Portugal, MIP surveillance was activated in 2014 and 2015, respectively, after the conclusion of the programmes. In the case of Cyprus, MIP surveillance was replaced by assistance programmes in the 2013-2015 period. With regard to Greece, this country was non eligible for AMR assessment in all the period analysed (MIP cycles 2012-2018). Spain with its financial sector programme was the only country that was always analysed in the AMR between 2012 and 2018.

Table 3

Main outcomes of MIP cycles for rescued countries, 2012-2018

\begin{tabular}{|c|c|c|c|c|c|}
\hline \multirow{2}{*}{$\begin{array}{c}\text { MIP } \\
\text { cycles } \\
\text { (year } \boldsymbol{t} \text { ) }\end{array}$} & $\begin{array}{c}\text { Number of countries } \\
\text { elected to IDRs }\end{array}$ & $\begin{array}{c}\text { Number of countries } \\
\text { non eligible for AMR } \\
\text { assessment }\end{array}$ & $\begin{array}{c}\text { Number of } \\
\text { countries } \\
\text { with no } \\
\text { imbalances }\end{array}$ & $\begin{array}{c}\text { Number of } \\
\text { countries with } \\
\text { imbalances }\end{array}$ & $\begin{array}{c}\text { Number of } \\
\text { countries with } \\
\text { excessive } \\
\text { imbalances }\end{array}$ \\
\hline 2012 & 12 & 4 (EL, IE, PT) & 0 & 12 (ES, CY) & 0 \\
\hline 2013 & 13 & 5 (EL, IE, PT, CY) & 0 & 11 & 2 (ES) \\
\hline 2014 & 17 & 4 (EL, CY, PT) & 3 & 11 (IE, ES) & 3 \\
\hline 2015 & 16 & 2 (EL, CY) & 0 & 11 (IE, ES) & 5 (PT) \\
\hline 2016 & 19 & 1 (EL) & 6 & 7 (IE, ES) & 6 (PT, CY) \\
\hline 2017 & 13 & 1 (EL) & 1 & 6 (IE, ES) & 6 (PT, CY) \\
\hline 2018 & 12 & 1 (EL) & 1 & 8 (IE, ES, PT) & $3(\mathbf{C Y})$ \\
\hline
\end{tabular}

Notes: a) When applicable, the programme countries are presented in parentheses; b) Croatia joined the EU on 1 July 2013.

The MIP was fully implemented for the first time in 2012. The EC published the first AMR in February and in May IDRs for 12 Member States were published and concluded on the existence of macroeconomic imbalances in all those countries, including Spain and Cyprus.

The number of Member States identified as having imbalances rose steadily between 2012 and 2015 (from 12 to 16). As stressed by the European Court of Auditors (2018), that number has also increased due to the exit of several countries from economic adjustment programmes and the accession of Croatia to the EU. More recently, the overall trend has reversed, probably as a consequence of the economic recovery of EU countries.

With regard to the four rescued countries analysed for the period between 2016 and 2018, the conclusion is that there were imbalances in Ireland and Spain, and excessive imbalances in Cyprus. In the case of Portugal, the imbalances were excessive in the first two years. Its macroeconomic situation improved in 2018, but some imbalances persist.

\section{IMPACT ON RESCUED EURO AREA COUNTRIES}

The crisis and policies implemented during and after the assistance programmes affected the economies of the five rescued EA countries in different ways. This section provides an analysis of the impact of these programmes on the rescued countries and of the patterns of divergence/convergence relative to the EA aggregate (19 countries) in the 2007-2016 period.

To compare the effects of assistance programmes, we analyse the growth rates of eight variables in a period of five years. As in the scoreboard of the MIP, the eight variables are divided into three main areas: external imbalances, internal imbalances and employment indicators. With the exception of real economic growth, all variables used correspond to the MIP headline indicators, but in this analysis all variables are considered as stock variables. 
Our aim is to identify the impact of the implementation of different programmes in the five countries, regardless of their initial macroeconomic situation. Thus, year 1 is the base year, and it corresponds to the year before the start of the programmes. Year 2 corresponds to the start of the respective assistance programmes: 2010 in the case of Greece and Ireland, 2011 for Portugal, 2012 for Spain and 2013 for Cyprus. The implementation of the programmes extended over the following three years (years 3 to 5 ).

As presented in Tables A.2 and A.3 in the Appendix and represented in the three figures below, all indices equal 100 in the base year. In subsequent years, the annual growth rates of the respective variables determine the evolution of the indices, denoting a worsening of the respective imbalance when the index increases or an improvement when the index decreases.

We analyse the indices of the current account balance (as a percentage of GDP) and of the net international investment position (as a percentage of GDP) to evaluate the evolution of the external imbalances in the period of implementation of the programmes. The respective two indices are presented in Figure 3 (see also Table A.2 in the Appendix).
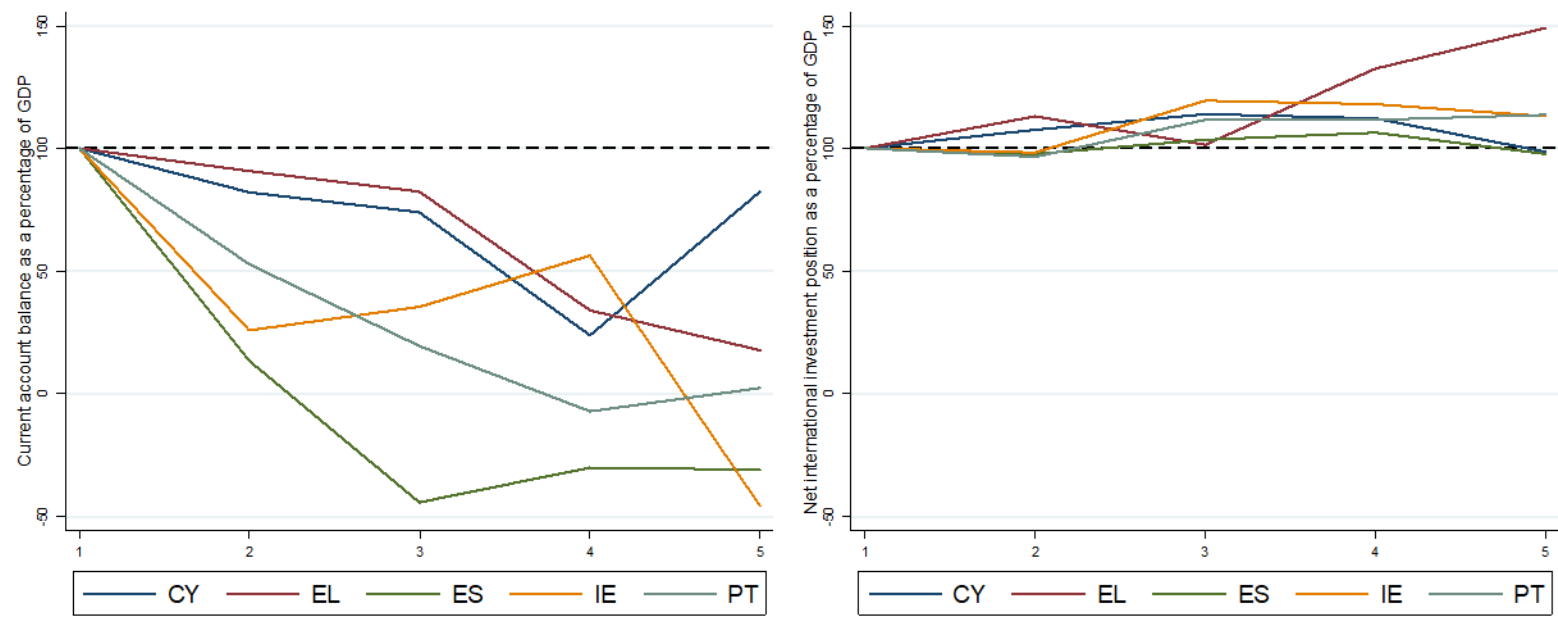

Figure 3. Impact of programmes on external imbalances

Source: Authors' calculations with data from AMECO and Eurostat

All assistance programmes contributed to some improvement of the current account deficits, but the trajectory was markedly different among countries. In year 5, only Ireland and Spain have a current account surplus. Regarding the net international investment position, there was a worsening in the case of Greece, Portugal and Ireland. Only the policy measures implemented in Spain and Cyprus were able to reduce their large stocks of net external liabilities. Thus, Spain's programme was the most effective in correcting external imbalances.

With respect to internal imbalances, we used four variables: real GDP, unemployment rate (as percentage of active population), public debt (as a percentage of GDP) and private sector debt (as a percentage of GDP). The respective indices are presented in Figure 4 (see also Table A.3 in the Appendix).

The measures implemented under the programmes caused an economic contraction in all countries, except in Ireland where there was moderate economic growth since the beginning of the programme (with a cumulative growth of $6.6 \%$ according to Table 4 ). The recession was very marked and continuous in Greece with a cumulative real GDP loss greater than $20 \%$. This loss was also relevant in Portugal $(6 \%)$.

The unemployment rates increased in the first years and declined in the last year. The exception was Greece, where the cumulative increase in the unemployment rate was extraordinarily high (186.5\%), which is evidence of the high deterioration of social conditions in this country.

The policies implemented increased mainly public debt but also private debt in all countries, except in Spain where there was a private sector deleveraging since the start of the financial assistance 
programme. With respect to public debt, it is worth highlighting the high global growth in Ireland (94.1\%) and the debt restructuring in Greece's second bailout in year 4 (corresponding to 2012).
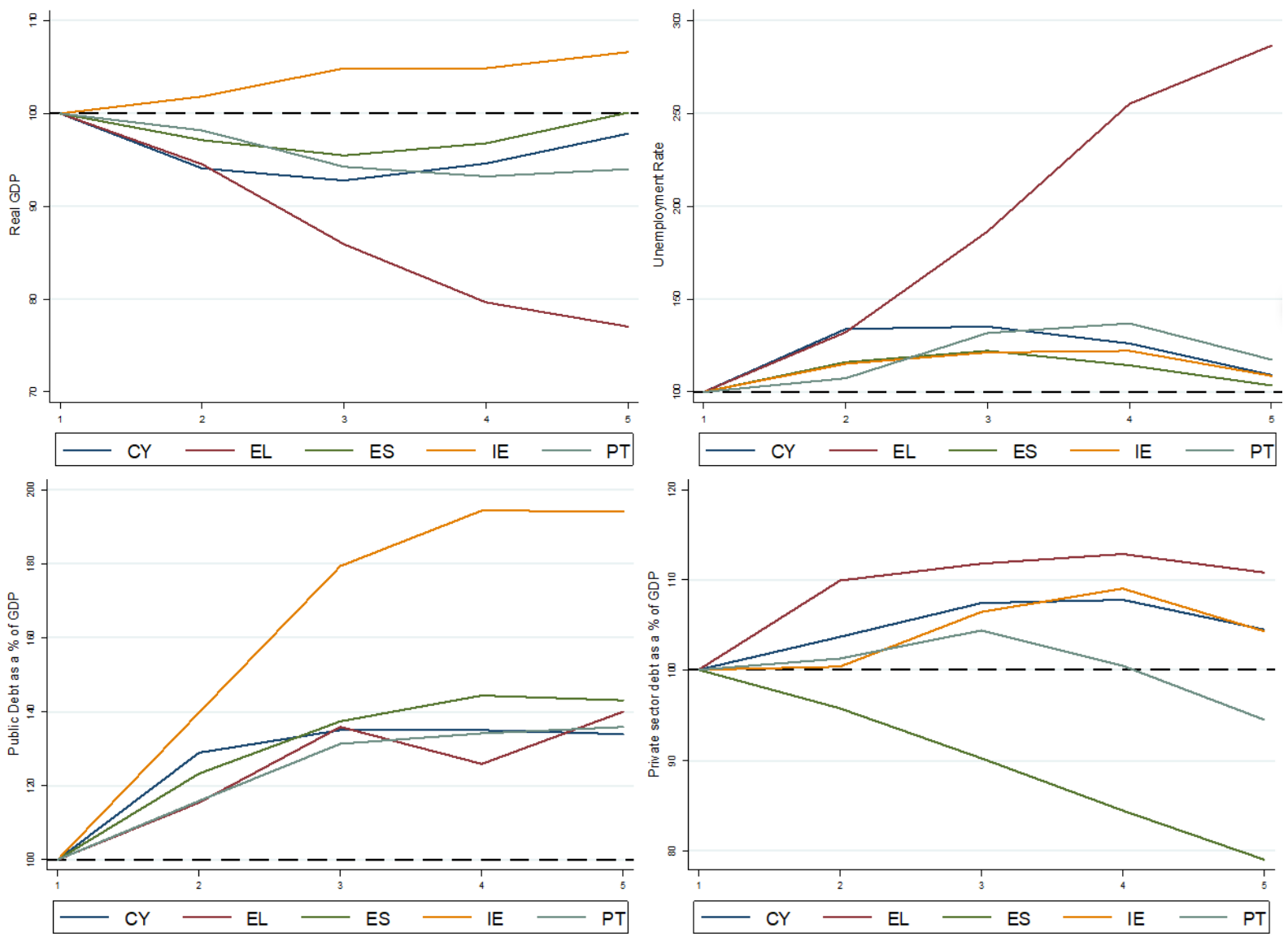

Figure 4. Impact of programmes on internal imbalances

Source: Authors' calculations with data from AMECO and Eurostat

To better take into account the analysis of employment, in Figure 5 the indices of the long-term unemployment rate (as a percentage of the active population aged 15-74) and of the youth unemployment rate (as a percentage of the active population aged 15-24) are presented (see also Table A.2 in the Appendix).
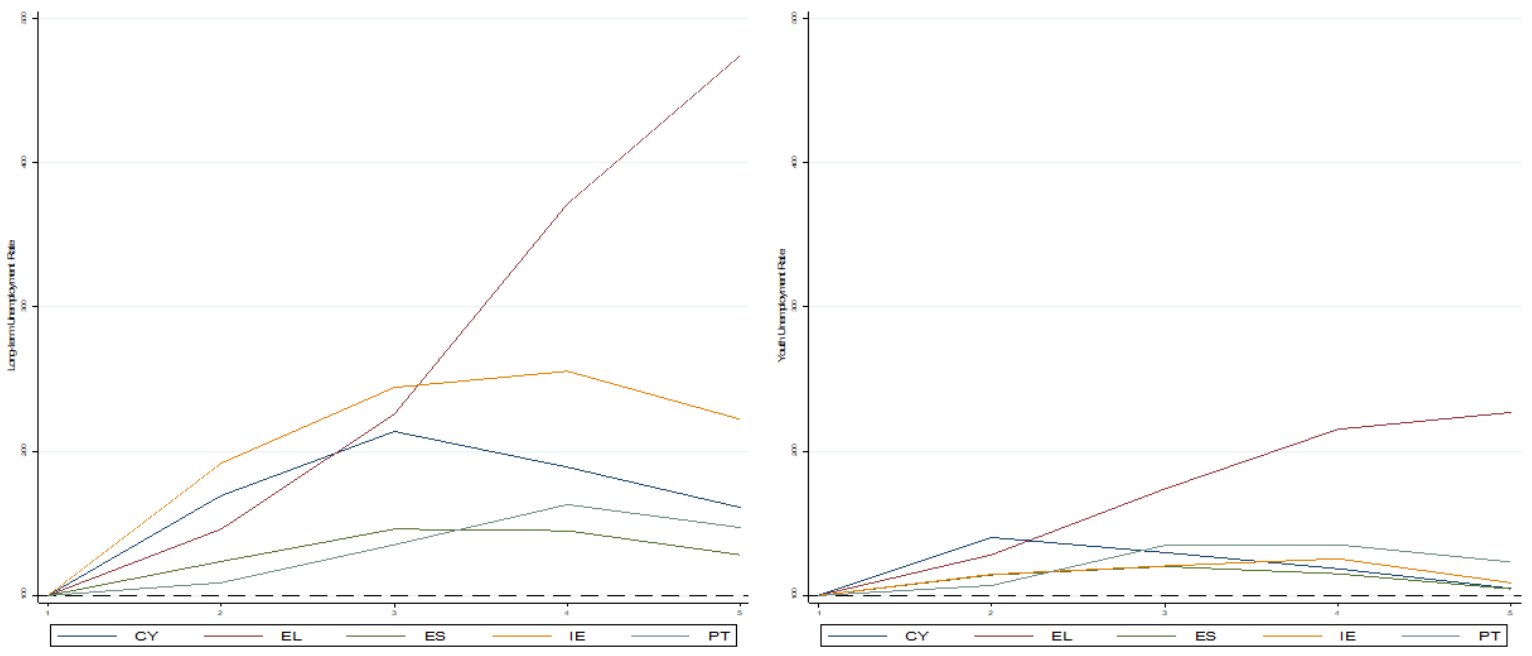

Figure 5. Impact of programmes on employment indicators

Source: Authors' calculations with data from AMECO and Eurostat 
As Figure 5 clearly shows, long-term unemployment registered very high growth rates in all rescued countries. Despite a slight improvement over the last year (except in Greece), the enormous cumulative increases (between 374.4\% in Greece and 28.1\% in Spain) expose important structural problems in these countries which require further policy action.

Young people have also been significantly affected by the phenomenon of unemployment, mainly in Greece and Portugal, where global growth rates attained $126.8 \%$ and $23 \%$, respectively. High youth unemployment rates undermine the growth potential of the respective economies, because young people usually attain higher levels of education than older people.

Table 4 makes clear the overall impact of the programmes in the five rescued countries. Greece stands out as the country where the implemented programmes most aggravated the respective external and internal imbalances. On the contrary, Spain improved its external imbalances, reduced private indebtedness with the lowest loss in terms of employment, albeit with the highest unemployment rates (total, long term and young) before the financial assistance programme.

Table 4

Global growth rates (\%)

\begin{tabular}{|c|c|c|c|c|c|c|c|c|}
\hline & \multicolumn{2}{|c|}{ External imbalances } & \multicolumn{4}{c|}{ Internal imbalances } & \multicolumn{2}{c|}{ Employment indicators } \\
\cline { 2 - 9 } Countries & $\begin{array}{c}\text { Current } \\
\text { account } \\
\text { balance }\end{array}$ & $\begin{array}{c}\text { Net } \\
\text { international } \\
\text { investment } \\
\text { position }\end{array}$ & $\begin{array}{c}\text { Gross } \\
\text { domestic } \\
\text { product }\end{array}$ & $\begin{array}{c}\text { Unemployment } \\
\text { rate }\end{array}$ & $\begin{array}{c}\text { Public } \\
\text { debt }\end{array}$ & $\begin{array}{c}\text { Private } \\
\text { sector } \\
\text { debt }\end{array}$ & $\begin{array}{c}\text { Long-term } \\
\text { unemployment } \\
\text { rate }\end{array}$ & $\begin{array}{c}\text { Youth } \\
\text { unemployment } \\
\text { rate }\end{array}$ \\
\hline CY & -17.7 & -1.5 & -2.2 & 9.2 & 33.8 & 4.5 & 61.1 & 5.1 \\
\hline EL & -82.4 & 49.0 & -23.0 & 186.5 & 40.0 & 10.8 & 374.4 & 126.8 \\
\hline ES & -130.8 & -2.4 & 0.1 & 3.3 & 43.0 & -21.0 & 28.1 & 4.5 \\
\hline IE & -145.6 & 13.0 & 6.6 & 8.7 & 94.1 & 4.3 & 122.2 & 8.9 \\
\hline PT & -97.5 & 13.7 & -6.0 & 17.5 & 35.8 & -5.5 & 47.4 & 23.0 \\
\hline
\end{tabular}

Source: Authors' calculations with data from AMECO and Eurostat

Ireland was the only country presenting a moderate economic growth in the analysed period, but the unemployment rates increased, mainly the long-term ones. Despite the marked improvement in the Irish current account, the growth of its public debt was very high and its private indebtedness and net external liabilities also get worse.

In Portugal, the implemented programme reduced external and private indebtedness, but it entailed a strong economic contraction and a great increase in unemployment, especially among long-term unemployed and young people. Similarly, Cyprus also performed well in terms of external and public indebtedness, but with considerable economic repercussions, particularly on the level of the long-term unemployment rate.

To analyse the evolution of the macroeconomic situation within the five rescued countries after the financial global crisis and to examine the patterns of convergence or divergence with respect to the EA aggregate, we use the headline indicators of MIP for the 2007-2016 period. ${ }^{2}$ In the Appendix, the 14 indicators for the five countries and for the EA aggregate are represented and grouped in 3 figures (Figures A.1, A.2 and A.3) that correspond to the three main areas: external imbalances and competitiveness (5 indicators), internal imbalances ( 6 indicators) and employment indicators (3

2 The MIP has created some tools for identifying unsustainable economic policies in EU Member States. Kamps et al. (2014) did a retrospective evaluation of the scoreboard since 2001 and concluded that if the MIP had been in place at the start of stage three of EA, the macroeconomic imbalances in the five rescued countries would have been identified early on. In 2004, the five countries exceeded five or more of the eleven indicators that were part of the scoreboard at the time of publication of their work. 
indicators). ${ }^{3}$ As the AMR at year $t$ uses scoreboard data up to year $t-2$, the data for the years between 2010 and 2016 correspond to data used in the AMR cycles 2012-2018.

With respect to external imbalances and competitiveness, Figure A.1 (in Appendix) reveals an overall convergence with respect to the EA average, with the exception of the net external liabilities. As observed in the graph of the net international investment position, the EA average was near the respective threshold in all periods while there was a deterioration of the situation of non-compliance with that threshold in all five countries. Ireland presents the largest negative divergence, but its evolution "appears to be driven by factors disconnected with the domestic economy" (European Commission, 2017a: 24).

Ireland stands out positively in the other four indicators. In 2015 and 2016, its moving average of the current account balance (as a percentage of GDP) is better than the EA average. Thus Ireland's situation is a result of competitiveness gains: a real effective devaluation greater than the respective threshold (in the period 2010-2013), an important decrease of the nominal unit labour cost index (mainly in 2008-2011 but also in 2013-2016) and, consequently, of an extraordinary increase in export market shares (since 2014). As presented in Table A.4 in the Appendix, the average of 5-year percentage change of export market shares in the analysed period is positive in Ireland $(2.2 \%)$ and negative in EA and in the other four countries (the absolute value of the average is above the lower limit in the case of Cyprus, Greece and Spain).

In relation to the other four countries, there are only two situations of non-compliance with the thresholds in 2016: Cyprus presents, similar to Ireland, a real effective devaluation greater than the respective threshold and Greece's export market share dropped more than the respective alert level.

Figure A.2 (in the Appendix) allows checking the internal imbalances of the five rescued countries through the six indicators of MIP. There is evident a divergence with respect to private and public debt (as a percentage of GDP), albeit the EA average also exceeds the respective threshold (since 2009 in the case of public debt). In the period 2007-2016, all countries exceed the threshold of private debt with the exception of Greece. There was a steady increase in the cases of Cyprus and Ireland and an improvement in the cases of Spain and Portugal since 2012. The public debt (as a percentage of GDP) increased mainly in Greece and Portugal, but also in Cyprus and Spain. Ireland's public debt started to decline in 2012 being slightly lower than the EA average in 2015 and 2016.

There was also a marked divergence regarding the unemployment rates until 2013. All five countries recorded an increase in their moving averages, but that increase was much higher than the threshold in Greece and Spain. From 2014 (2012 in Ireland) these moving averages decreased, but only Ireland and to a lesser degree Portugal and Cyprus converge to the EA average in 2016.

With respect to the other three indicators, the situations of non-compliance with the alert levels have been corrected over the analysed period: Cyprus experienced a huge increase in financial sector liabilities between 2007 and 2008; all five countries have reduced their private sector credit flows; and Ireland presented a strong rebound in house prices in 2014, "mainly driven by supply constraints" (European Commission, 2017a: 24).

Notwithstanding the convergence in 2016 of the employment indicators with respect to the respective thresholds and the EA average, Figure A.3 (in the Appendix) confirms that the crisis and the assistance programmes have affected the five rescued countries in different ways and degrees. The most divergent situations with respect to the alert levels occurred in Greece, Spain and Cyprus in terms of longterm unemployment rates, but also as concerns to youth unemployment rates. In 2007-2016 period, the average of these two indicators was higher than the respective thresholds in all five countries. For example, Greece's average was 7.8 times higher than the threshold set for the change of the long-term

3 We use the "Latest live data for the scoreboard indicators" compiled by Eurostat (available on http://ec.europa.eu/eurostat/web/macroeconomic-imbalances-procedure/indicators). As the data compiled by Eurostat are regularly updated, they may differ from those used for the respective AMRs. 
unemployment rate and in Spain the average was 4.3 times higher than the alert level for the change in the youth unemployment rate (Table A.4, in the Appendix).

In Ireland, there was a strong fall in the activity rate between 2007 and 2010, and thus there was a breach of the threshold between 2009 and 2012. Portugal also showed a reduction in the activity rate higher than the respective threshold between 2013 and 2014.

Ten years after the Great Recession, the economic situation in the EU and the EA has undoubtedly improved. In 2017, and for the first time since the beginning of the crisis, all Member States of the EU saw their economies expand and the number of employed persons in the EA was at its highest level since 1999. However, the moderation of growth in 2018 was more pronounced than expected, and the winter forecasts published in February 2019 by the European Commission (2019) for the present year also suggest a growth rate of $1.3 \%$ in the EA, lower than what was forecast in autumn 2018 (1.9\%). The same holds true for the five rescued countries, with the exception of Greece, for which the growth forecasts suggest a continued growth but at lower rates than in 2018. Since some vulnerabilities are still present in the rescued countries and the future of the global economy is uncertain, it is even more appropriate to reflect on the lessons for economic policy that stem from the analysis of the causes of the last financial crisis, and also from the application of the MIP since 2011.

\section{IMPLICATIONS AND LESSONS FOR ECONOMIC POLICY}

From a historical perspective, the recent global crisis is universally considered as unique in the period after World War II in terms of its exceptional size and extent. Notwithstanding its remarkable proportions, several authors (European Commission, 2009; Claessens et al. 2009, 2010) also agree that this crisis has several features in common with similar financial crises in the past that were followed by subsequent economic recessions, such as in Japan and the Nordic European countries in the early 1990s or the Asian crisis in the late 1990s.

The crisis of the 1990s occurred after a long period of peace, prosperity and growth, and surprised policy-makers and the public in general because they had believed that macroeconomic instability had been eradicated. In fact, the 'Great Moderation', with low and stable inflation, low real interest rates and sustained growth, was conducive to a perception of low risk and a high return on capital. Some of these factors created excessive optimism, which, jointly with policy and regulatory deficiencies, led to market failures (Claessens et al., 2009). In the 1990s, the world economy was hit by a series of unusually deep crises in a context of turbulent events, such the Gulf War, the implosion of the Soviet Empire and the demolition of the Iron Curtain. The industrial world entered a recession, triggered by rising oil prices and increasing real interest rates. In Europe, as a result of the re-unification of Germany, the Bundesbank increased its interest rate in response to the expansionary fiscal policy. In autumn 1992 and summer 1993, the recession culminated with the exchange rate mechanism crisis. Finland and Sweden were the first countries to be affected, experiencing unusually deep and prolonged depressions (Jonung \& Hagberg, 2005).

The historical comparison between the recent episode and earlier major financial crises in the postwar period reveals the presence of similar stresses in the financial system (Claessens et al. 2009, 2010; Bordo \& Haubrich, 2010, Kenc \& Dibooglu 2010; Bagliano \& Morana, 2012). In general, the literature demonstrates that most major financial crises in the past were also preceded by a sustained period of credit booms, low risk premiums and rapid increases in asset prices. Specifically, recessions associated with credit crunches and house price busts have tended to be deeper and longer than others. These episodes of large credit expansion not only reflect macroeconomic conditions but are also associated with failures in the regulation and supervision of financial institutions.

Concerning the differences from previous episodes, the last crisis presents at least four new aspects (Claessens et al., 2010): (i) there was a widespread use of complex and opaque financial instruments; (ii) the interconnectedness between global financial markets had increased over a short time period; (iii) the 
degree of leverage of financial institutions accelerated sharply; and (iv) the household sector played a central role. These new elements, combined with those factors observed in more traditional boom and bust cycles, resulted in an unprecedented financial crisis.

Summing up, macroeconomic factors and developments in the functioning of the financial markets were the global forces behind the most recent crisis and the previous ones. These factors address issues related to the large build-ups of macroeconomic imbalances that were at the heart of the crisis. In Europe, the gap in competitiveness and the consequent imbalances resulted in economic asymmetries between countries (especially the peripheral countries). Europe's policymakers were convinced that the move to a monetary union was a mechanism to enhance credibility that would lower the borrowing costs for weaker countries and was the only way to avoid the risk of periodic crises with currency realignments (Bordo \& James, 2014). A common currency was envisaged before economic integration as a powerful driver of convergence, and it was assumed that its trade-creation effect would result in a higher degree of businesscycle synchronization (Frankel \& Rose, 1998). The original architecture of the EMU therefore essentially rested on an independent central bank that was oriented towards price stability, and a commitment to budgetary discipline.

This architecture proved to be incomplete (Pisani-Ferry, 2013). The SGP was designed to enforce fiscal discipline in the Member States of the EU "while allowing them to respond, within certain bounds, flexibly and effectively to the cycle" (van den Noord, 2007: 36). Nevertheless, the European sovereign debt crisis provides eloquent proof that the SGP was unable to accomplish these objectives, since it has been unable to prevent the deficit bias and the pro-cyclicality of fiscal policy in periods of economic expansion. The Maastricht Treaty did not include the prevention of non-fiscal imbalances, because financial instability was perceived as being of minor importance at that time, being the EMU "conceived as an economic and monetary union, not as a financial union" (Pisani-Ferry, 2013: 11). Thereafter, countries did not adjust their economies internally, and the macroeconomic imbalances grew too large.

The correction of the imbalances and structural vulnerabilities began in 2008, and the pace of adjustment varied significantly across countries and accelerated after 2010 (Moro, 2014). The persistence of imbalances and excessive imbalances in several countries leads to a reflection on the effectiveness of the MIP. In this respect, problematic aspects in the institutional design of the MIP and its operating procedures were identified. The national economic policies that were implemented are far from being sufficient to address the remaining inefficiencies, although the correction of imbalances is in the national interest (Franco \& Zollino, 2014). The identification by the EC of excessive imbalances in some countries meant there was a greater need for policy action, but the countries with excessive imbalances did not implement significantly more reforms than the other countries (Pierluigi \& Sondermann, 2018). However, it is important to emphasize that it is not straightforward to design policies to correct the macroeconomic vulnerabilities that were detected. Moreover, the action of national governments will prove incomplete and ineffective when the imbalances depend on developments outside the domestic economy. In this respect, Gros (2012: 10) stresses that "there is little a government can do in a market economy to force lower wages in the private sector" with the aim of improving competitiveness.

Since 2012, the EC has identified a large number of countries exhibiting macroeconomic imbalances, some countries persistently, but it has never invoked the corrective arm of the MIP for any country; under this, the countries would be asked to commit to specific policy measures. Several authors and institutions (European Central Bank, 2018; European Court of Auditors, 2018) agree that the MIP has been more successful in identifying macroeconomic imbalances than in correcting them and, thus, the activation of the corrective arm could increase its effectiveness.

The application of asymmetric rules between net-debtor countries and net-creditor countries and the one-country focus have also been criticized. EU debtor countries are asked to cut labour costs and reduce deficits, while creditor countries are not requested to share the burden of adjustment by stimulating their aggregate demand (Moschella, 2014). Additionally, the monitoring activity in the past was excessively focused on domestic economic policies and their future developments, notwithstanding the cross-border 
relevance of some countries (such as Spain). Policy recommendations for one country should take account of the externalities in other member countries, but the problem is even more complicated because the adjustment costs are mainly supported by one country while the expected benefits of stability spread across the whole euro area (Franco \& Zollino, 2014).

The separation between the MIP and the SGP has also been criticised. The impact of fiscal policies on external imbalances is not always taken into account in country-specific recommendations, even when the external imbalances identified are strongly linked to fiscal policy (European Court of Auditors, 2018). Kamps et al. (2014) outline the fact that the developments in the period 1999-2011 have revealed the interconnectedness of unsustainable fiscal policies and macroeconomic imbalances, and thus it will be important in the future to establish common procedures between the MIP and the SGP. For example, the European Fiscal Board (2017) has suggested introducing a link to the MIP in the SGP, because macroeconomic imbalances negatively affect fiscal sustainability.

As has been analysed above, the flow imbalances diminished in the period 2012-2018, but the rescued countries remain characterised by large negative net international investment positions coupled with large stocks of government debt and also, with exception of Greece, of private debt. The persistence of large stocks imbalances constitutes a potential problem, since they continually have to be rolled over. In order for the net international investment position to converge back towards its threshold value of the MIP within a decade, and thus to guarantee external sustainability, it is necessary that all the rescued countries, with the exception of Ireland, have higher current account surpluses than the current levels. These countries, troubled by high debt, have also relatively less room for relying on potential output growth for a reduction in debt ratios. Pierluigi \& Sondermann (2018) emphasize that Portugal, Spain and Greece have economic structures that are less efficient than the other EU countries, and thus a large part of their imbalances are explained by structural factors. The potential deleveraging needs that have been identified are therefore not an immediate threat to debt sustainability, but they suggest that these countries are more vulnerable in the event of adverse shocks to growth and interest rates.

The persistence of some vulnerabilities is a concern in a context of increasing risk. The latest European economic forecasts from the European Commission (2019: 1), published in February 2019, show "growth moderates amid high uncertainty". In the external environment, there is increased uncertainty regarding trade policies, notably between the US and China, and the abrupt tightening of the US fiscal policy is now more likely than before. As a result of high asset valuations, global financial markets are more vulnerable to less supportive financial conditions, which may result from changes in investors' perceptions of global economic growth and in their appetite for risk. In the euro area, the risks of the resumption of negative sovereign-bank loops persist in some countries, and there are also social tensions and political instability. Great uncertainty still surrounds the Brexit decision of 2016, but also the future consequences of the Catalan referendum in 2017 and other electoral results that reflect an increase in ultra-right wing political forces and have signalled an increased anti-European popular sentiment since 2017 (EuroMemo Group, 2018).

These geopolitical tensions may involve a shift to more inward-looking policies (European Commission, 2018), but the European integration process and the EU coordination of policy should instead be reinforced. Several steps have been conducted to strengthen and improve the EMU's economic governance framework, including the Five Presidents' Report of June 2015 (Juncker, 2015) and the EC's May 2017 Reflection Paper on the deepening of the EA (European Commission, 2017b). It is recognized that an essential element for the successful performance of the EMU in the long run is the "convergence towards more resilient economic and social structures in Member States" (European Commission, 2017b, p. 23). However, the financial and economic crises stopped the convergence trend in the EMU, and ten years later the process of re-convergence is not yet obvious (European Commission, 2017b). As has been analysed in the previous section, in the period 2007-2016 the economies of the five rescued countries diverged from the EA average in three main indicators of imbalances: net external liabilities, private debt and public debt. Additionally, in AMR 2018, the rescued countries, with the exception of Ireland, present 
high unemployment rates (higher than the respective threshold of $10 \%$ ), which signal the persistence of social divergence in the EMU.

As concerns the monetary and financial dimension of the EMU, it is now evident that it is essential to preserve financial stability, since "financial crises often lead to fiscal crises" (Mishkin, 2017, p. 256). Thus, new macroprudential policies and agencies, like the European Systemic Risk Board, emerged after the financial crisis in order to protect the financial system of the EMU from fluctuations in the real economy. However, Haldane (2014) cautions that both academics and policymakers should take time to research the effectiveness of these policies and to adapt them in the light of experience. Additionally, the ECB stopped its net asset purchase programme in December 2018, which implies that there are new risks for the economic growth of the EA countries and their public finances. The high levels of indebtedness of the rescued countries mean that the interest costs could increase markedly if EA interest rates were to normalise. Large amounts of so-called "non-performing loans", mainly in Greece, Cyprus and Portugal, also represent a source of vulnerability in the financial and banking sectors in these countries.

In sum, the identification of macroeconomic imbalances in scope of the MIP, and the present higher awareness of the risks associated with those imbalances, mainly in a global economic context of high uncertainty, should in the future lead to the implementation by national governments of policies and reforms that are truly committed to addressing these imbalances.

\section{CONCLUSION}

The Great Recession has exposed important structural and institutional weaknesses in the European Project. Based on the principles of "no default, no bailout and no exit", the EU failed doubly in crisis prevention and its resolution. As a result, the macroeconomic imbalances in some EA countries were aggravated and financial assistance was inevitable.

To benefit from the loans of the EU and IMF, Greece, Ireland, Portugal and Cyprus were subject to macroeconomic adjustment programmes, with surveillance of their imbalances and monitoring of corrective measures taking place in the context of these programmes. In Spain, a financial assistance programme for the recapitalization of financial institutions was implemented.

This paper has examined the effects of the recent European crisis and the impact of the assistance programmes in the five rescued countries, by using the scoreboard of headline indicators of the MIP as reference. These indicators are aggregated into three main areas: external imbalances and competitiveness; internal imbalances; and employment indicators.

Specifically, to compare the effects of assistance programmes, we have analysed the growth of eight variables, over a period of five years, classified in the same three areas as in MIP. We have concluded that Spain's programme was the most effective in correcting external imbalances and private indebtedness. Second, Greece stands out as the country where the programmes most aggravated the respective external and internal imbalances. Third, Ireland was the only country presenting a moderate economic growth, but the unemployment rates increased, mainly the long-term ones. Fourth, in Portugal, the implemented programme reduced external and private indebtedness, but it caused a strong economic contraction and an increase in unemployment. Finally, Cyprus also performed well in terms of external and public indebtedness, but with considerable economic repercussions, particularly on the level of the long-term unemployment rate.

To analyse the evolution of the macroeconomic situation within the five rescued countries and the patterns of divergence/convergence relative to the EA aggregate, over the 2007-2016 period, we used all the 14 headline indicators of MIP. The results indicate that, over the period examined, the figures for these five countries have diverged considerably from the thresholds and the EA averages, mainly in relation to four indicators: the net international investment position, private sector debt and public debt and unemployment rates until 2013. 
The analysis carried out in this paper has shown that the assistance programmes and the option of austerity adopted to deal with the crisis has led to economic recession in the rescued countries, with more external and public debt, more unemployment and, in general, worsening social conditions. As a result, ten years after the beginning of the European crisis, although the economic situation has improved in the EU and EA, the effects of the crisis and of the austerity policies continue to be alive in some rescued countries and the macroeconomic imbalances persist after the end of the assistance programmes, being classified as excessive imbalances in Cyprus.

While our study sheds new light on the role played by the assistance programmes in the evolution of macroeconomic imbalances in the rescued countries, and on their processes of divergence/convergence relative to the euro area, it must be accompanied by certain caveats. One important limitation of our analysis results from the fact that we do not consider the impact of the initial economic conditions of these countries on their path after the start of the crisis. Another limitation concerns data availability and the inherent methodological options. We have performed a descriptive statistical analysis, and no causal econometric inference is (or is intended to be) made. Further research will require an enlargement of the size of the sample to allow us the application of alternative econometric methods (e.g. VAR models). In fact, while some empirical work has been done, the relevance of this topic and the expectations of the emergence of another crisis in the future point to a forthcoming research agenda.

\section{ACKNOWLEDGEMENT}

This article had the support of Centre for Transdisciplinary Development Studies (CETRAD) which is supported by national funds, through the FCT - Portuguese Foundation for Science and Technology under the project UID/SOC/04011/2019.

\section{REFERENCES}

Bagliano, F. \& Morana, C. (2012). The Great Recession: US dynamics and spillovers to the world economy. Journal of Banking \& Finance, 36, 1-13.

Bordo, M. \& Haubrich, J. (2010). Credit crises, money and contractions: an historical view. Journal of Monetary Economics, 57, 1-18.

Bordo, M. \& James, Harold (2014): The European Crisis in the Context of the History of Previous Financial Crises. Journal of Macroeconomics, 39, 275-284.

Claessens, S., Kose, M. A. \& Terrones, M. E. (2009). What happens during recessions, crunches and busts? Economic Policy, 60, 653-700.

Claessens, S., Kose, M. A. \& Terrones, M. E. (2010). The global financial crisis: How similar? How different? How costly? Journal of Asian Economics, 21, 247-264.

Correia, L. (2016). The European Crisis: Repercussions on the Portuguese Economy. Athens Journal of Mediterranean Studies, 2(2), 129-144.

De Grauwe, P. (2007). Some Thoughts on Reforming the Stability and Growth Pact. In F. Breuss (ed), The Stability and Growth Pact - Experiences and Future Aspects. Vienna, Springer.

EuroMemo Group (2018). Can the EU still be saved? The implications of a multi-speed Europe. EuroMemorandum 2018 (available at http://www2.euromemorandum.eu/uploads/euromemorandum_2018.pdf).

European Central Bank (2018). The European Commission's 2018 assessment of macroeconomic imbalances and progress on reforms. Economic Bulletin, 2, 69-72.

European Commission (2009). Economic Crisis in Europe: Causes, Consequences and Responses. European Economy, № 7. Office for Official Publications of the European Communities, Luxembourg.

European Commission (2012). Scoreboard for the surveillance of macroeconomic imbalances. European Economy, No 92. European Commission, Brussels.

European Commission (2015). Adding employment indicators to the scoreboard of the Macroeconomic Imbalance Procedure to better capture employment and social developments. European Commission, Brussels.

European Commission (2016). The Macroeconomic Imbalance Procedure - Rationale, Process, Application: A Compendium. European Economy, No. 39. Publications Office of the European Union, Luxembourg. 
European Commission (2017a). 2017 European Semester: Assessment of progress on structural reforms, prevention and correction of macroeconomic imbalances, and results of in-depth reviews under Regulation (EU) No 1176/2011. COM (2017) 90 final. European Commission, Brussels.

European Commission (2017b). Reflection Paper on the Deepening of the Economic and Monetary Union. European Commission, Brussels.

European Commission (2018). Alert Mechanism Report 2019. COM(2018), 758 final. European Commission, Brussels.

European Commission (2019). European Economic Forecast Winter 2019 (Interim). Institutional Paper 096. European Commission, Brussels.

European Court of Auditors (2018). Audit of the Macroeconomic Imbalance Procedure (MIP). Special Report $\mathrm{n}^{\mathrm{o}}$ 3. European Union, Luxembourg.

European Fiscal Board (2017). Annual Report. October 2017. European Commission, Brussels.

Franco, D. \& Zollino, F. (2014). Macroeconomic imbalances in Europe: institutional progress and the challenges that remain. Applied Economics, 46(6), 589-602.

Frankel, J.A. \& Rose, A., 1998. The endogeneity of the optimum currency area criteria. The Economic Journal, 108, 1009-1025.

Gibson, H. D., Palivos, T. \& Tavlas, G. S. (2014). The crisis in the euro area: an analytic overview. Journal of Macroeconomics, 39: 233-239.

Gros, D. (2012). How to deal with macroeconomic imbalances? Centre for European Policy Studies Special Report, N. ${ }^{\circ}$ 69/November 2012.

Haldane, A. (2014). Macroprudential Policy in Prospect. In G. Akerlof, O. Blanchard, D. Romer, \& J. Stiglitz (ed). What Have We Learned? Macroeconomic Policy after the Crisis. Cambridge, MIT press.

Howarth, D. \& Quaglia, L. (2016). The Political Economy of European Banking Union. Oxford, Oxford University Press.

Jonung, G. \& Hagberg, T. (2005). How costly was the crisis of the 1990s? A comparative analysis of the deepest crises in Finland and Sweden over the last 130 years. European Economy, Economic Papers 224, European Commission, Brussels.

Junker, Jean-Claude (2015). The Five Presidents' Report: Completing Europe's Economic and Monetary Union. European Commission, Brussels.

Kamps, C., de Stefani, R., Leiner-Killinger, N., Rüffer, R. \& Sondermann, D. (2014). The identification of fiscal and macroeconomic imbalances - unexploited synergies under the strengthened EU governance framework. ECB Occasional Paper, No. 157.

Kenc, T. \& Dibooglu, S. (2010). The 2007-2009 financial crisis, global imbalances and capital flows: implications for reform. Economic Systems, 34, 3-21.

Mishkin, F. S. (2017). Rethinking monetary policy after the crisis. Journal of International Money and Finance, 73, $252-274$.

Moro, B. (2014). Lessons from the European economic and financial great crisis: a survey. European Journal of Political Economy, 34, S9-S24.

Moschella, M. (2014). Monitoring Macroeconomic Imbalances: Is EU Surveillance More Effective than IMF Surveillance? Journal of Common Market Studies, 52(6), 1273-1289.

Pierluigi, B. \& Sondermann, D. (2018). Macroeconomic imbalances in the euro area: where do we stand? Series ECB Occasional Paper Series N. ${ }^{\circ} 211$ / June 2018.

Pisani-Ferry, J. (2013). The known unknowns and unknown unknowns of European Monetary Union. Journal of International Money and Finance, 34, 6-14.

Stiglitz, J. E. (2016). The Euro: How a Common Currency Threatens the Future of Europe. New York, Norton Company.

Van den Noord, P. (2007). Fiscal Policies in EMU at the Crossroads. In F. Breuss (ed.), The Stability and Growth PactExperiences and Future Aspects, Vienna, Springer.

Wajda-Lichy, M. (2015). Excessive current account surpluses in euro zone economies -problem of particular economies or the euro area as a whole? Journal of International Studies, 8(3), 99-111.

Zestos, G. K. (2016). The Global Financial Crisis: From US Subprime Mortgages to European Sovereign Debt. London, Routledge, Taylor \& Francis Group. 


\section{Appendix}

Table A.1

Ratio government consolidated gross debt /GDP, 1999-2017 (\%)

\begin{tabular}{|c|c|c|c|c|c|c|c|c|c|c|c|c|c|c|c|c|c|c|c|}
\hline Country & 1999 & 2000 & 2001 & 2002 & 2003 & 2004 & 2005 & 2006 & 2007 & 2008 & 2009 & 2010 & 2011 & 2012 & 2013 & 2014 & 2015 & 2016 & 2017 \\
\hline Austria & 66.7 & 66.1 & 66.7 & 66.7 & 65.9 & 65.2 & 68.6 & 67.3 & 65.0 & 68.7 & 79.9 & 82.7 & 82.4 & 81.9 & 81.3 & 84.0 & 84.6 & 83.6 & 78.4 \\
\hline Belgium & 114.4 & 108.8 & 107.6 & 104.7 & 101.1 & 96.5 & 94.7 & 91.1 & 87.0 & 92.5 & 99.5 & 99.7 & 102.6 & 104.3 & 105.5 & 107.0 & 106.1 & 105.9 & 103.1 \\
\hline Cyprus & 54.8 & 54.9 & 56.5 & 59.7 & 63.1 & 64.1 & 62.8 & 58.7 & 53.5 & 45.1 & 53.8 & 56.3 & 65.7 & 79.7 & 102.6 & 107.5 & 107.5 & 106.6 & 97.5 \\
\hline Estonia & 6.5 & 5.1 & 4.8 & 5.7 & 5.6 & 5.1 & 4.5 & 4.4 & 3.7 & 4.5 & 7.0 & 6.6 & 6.1 & 9.7 & 10.2 & 10.7 & 10.0 & 9.4 & 9.0 \\
\hline Finland & 44.1 & 42.5 & 41.0 & 40.2 & 42.8 & 42.7 & 40.0 & 38.2 & 34.0 & 32.7 & 41.7 & 47.1 & 48.5 & 53.9 & 56.5 & 60.2 & 63.5 & 63.0 & 61.4 \\
\hline France & 60.2 & 58.6 & 58.1 & 60.0 & 64.1 & 65.7 & 67.2 & 64.4 & 64.4 & 68.7 & 82.9 & 85.1 & 87.8 & 90.7 & 93.5 & 94.9 & 95.6 & 96.6 & 97.0 \\
\hline Germany & 60.0 & 58.9 & 57.7 & 59.4 & 63.1 & 64.8 & 67.0 & 66.5 & 63.7 & 65.2 & 72.6 & 80.9 & 78.6 & 79.8 & 77.5 & 74.7 & 71.0 & 68.2 & 64.1 \\
\hline Greece & 98.9 & 104.9 & 107.1 & 104.9 & 101.5 & 102.9 & 107.4 & 103.6 & 103.1 & 109.4 & 126.7 & 146.2 & 172.1 & 159.6 & 177.4 & 178.9 & 176.8 & 180.8 & 178.6 \\
\hline Ireland & 46.7 & 36.1 & 33.2 & 30.6 & 29.9 & 28.2 & 26.1 & 23.6 & 23.9 & 42.4 & 61.5 & 86.1 & 110.3 & 119.6 & 119.4 & 104.5 & 76.9 & 72.8 & 68.0 \\
\hline Italy & 109.7 & 105.1 & 104.7 & 101.9 & 100.5 & 100.1 & 101.9 & 102.6 & 99.8 & 102.4 & 112.5 & 115.4 & 116.5 & 123.4 & 129.0 & 131.8 & 131.5 & 132.0 & 131.8 \\
\hline Latvia & 12.1 & 12.1 & 13.8 & 13.0 & 13.7 & 14.0 & 11.4 & 9.6 & 8.0 & 18.2 & 35.8 & 46.8 & 42.7 & 41.2 & 39.0 & 40.9 & 36.8 & 40.5 & 40.1 \\
\hline Lithuania & 22.7 & 23.5 & 22.9 & 22.1 & 20.4 & 18.7 & 17.6 & 17.2 & 15.9 & 14.6 & 28.0 & 36.2 & 37.2 & 39.8 & 38.8 & 40.5 & 42.6 & 40.1 & 39.7 \\
\hline Luxembourg & 7.8 & 7.2 & 7.3 & 7.0 & 6.9 & 7.3 & 7.4 & 7.8 & 7.7 & 14.9 & 15.7 & 19.8 & 18.7 & 22.0 & 23.7 & 22.7 & 22.0 & 20.8 & 23.0 \\
\hline Malta & 62.1 & 60.9 & 65.2 & 63.2 & 69.0 & 71.9 & 70.0 & 64.5 & 62.3 & 62.6 & 67.6 & 67.5 & 70.1 & 67.8 & 68.4 & 63.8 & 58.7 & 56.2 & 50.8 \\
\hline Netherlands & 58.4 & 51.7 & 49.1 & 48.4 & 49.6 & 49.8 & 49.2 & 44.7 & 42.7 & 54.7 & 56.8 & 59.3 & 61.6 & 66.3 & 67.8 & 68.0 & 64.6 & 61.8 & 56.7 \\
\hline Portugal & 51.0 & 50.3 & 53.4 & 56.2 & 58.7 & 62.0 & 67.4 & 69.2 & 68.4 & 71.7 & 83.6 & 96.2 & 111.4 & 126.2 & 129.0 & 130.6 & 128.8 & 129.9 & 125.7 \\
\hline Slovakia & 47.1 & 49.6 & 48.3 & 42.9 & 41.6 & 40.6 & 34.1 & 31.0 & 30.1 & 28.5 & 36.3 & 41.2 & 43.7 & 52.2 & 54.7 & 53.5 & 52.3 & 51.8 & 50.9 \\
\hline Slovenia & 23.7 & 25.9 & 26.1 & 27.3 & 26.7 & 26.8 & 26.3 & 26.0 & 22.8 & 21.8 & 34.6 & 38.4 & 46.6 & 53.8 & 70.4 & 80.3 & 82.6 & 78.6 & 73.6 \\
\hline Spain & 60.9 & 58.0 & 54.2 & 51.3 & 47.6 & 45.3 & 42.3 & 38.9 & 35.6 & 39.5 & 52.8 & 60.1 & 69.5 & 85.7 & 95.5 & 100.4 & 99.4 & 99.0 & 98.3 \\
\hline 19EA & 70.6 & 68.1 & 67.0 & 66.9 & 68.1 & 68.4 & 69.2 & 67.4 & 65.0 & 68.7 & 79.2 & 84.8 & 87.3 & 91.7 & 93.9 & 94.2 & 92.1 & 91.1 & \begin{tabular}{|l|}
88.8 \\
\end{tabular} \\
\hline
\end{tabular}

Source: AMECO 
Table A.2

Indices of external imbalances and employment indicators

\begin{tabular}{|c|c|c|c|c|c|c|c|c|c|c|c|c|c|c|}
\hline \multirow{3}{*}{ Country } & \multirow{3}{*}{ Year $\mathrm{t}$} & \multirow{3}{*}{ Year } & \multicolumn{6}{|c|}{ External imbalances } & \multicolumn{6}{|c|}{ Employment indicators } \\
\hline & & & \multicolumn{3}{|c|}{ Current account balance } & \multicolumn{3}{|c|}{$\begin{array}{c}\text { Net international } \\
\text { investment position }\end{array}$} & \multicolumn{3}{|c|}{$\begin{array}{c}\text { Long-term unemployment } \\
\text { rate }\end{array}$} & \multicolumn{3}{|c|}{ Youth unemployment rate } \\
\hline & & & $\begin{array}{l}\% \text { of } \\
\text { GDP }\end{array}$ & $\begin{array}{l}\text { Annual } \\
\text { growth } \\
\text { rate }\end{array}$ & Index & $\begin{array}{l}\% \text { of } \\
\text { GDP }\end{array}$ & $\begin{array}{l}\text { Annual } \\
\text { growth } \\
\text { rate }\end{array}$ & Index & $\begin{array}{c}\% \text { of } \\
\text { active } \\
\text { population }\end{array}$ & $\begin{array}{l}\text { Annual } \\
\text { growth } \\
\text { rate }\end{array}$ & Index & $\begin{array}{c}\% \text { of } \\
\text { active } \\
\text { population }\end{array}$ & $\begin{array}{l}\text { Annual } \\
\text { growth } \\
\text { rate }\end{array}$ & Index \\
\hline \multirow{5}{*}{$\mathrm{CY}$} & 1 & 2012 & -5.93 & . & 100.00 & -129.10 & . & 100.00 & 3.60 & . & 100.00 & 27.70 & . & 100.00 \\
\hline & 2 & 2013 & -4.87 & -0.179 & 82.12 & -138.70 & 0.074 & 107.44 & 6.10 & 0.694 & 169.44 & 38.90 & 0.404 & 140.43 \\
\hline & 3 & 2014 & -4.38 & -0.101 & 73.84 & -147.00 & 0.060 & 113.87 & 7.70 & 0.262 & 213.89 & 36.00 & -0.075 & 129.96 \\
\hline & 4 & 2015 & -1.42 & -0.676 & 23.90 & -145.00 & -0.014 & 112.32 & 6.80 & -0.117 & 188.89 & 32.80 & -0.089 & 118.41 \\
\hline & 5 & 2016 & -4.88 & 2.443 & 82.28 & -127.20 & -0.123 & 98.53 & 5.80 & -0.147 & 161.11 & 29.10 & -0.113 & 105.05 \\
\hline \multirow{5}{*}{ EL } & 1 & 2009 & -12.51 & . & 100.00 & -87.50 & . & 100.00 & 3.90 & . & 100.00 & 25.70 & . & 100.00 \\
\hline & 2 & 2010 & -11.34 & -0.094 & 90.63 & -99.00 & 0.131 & 113.14 & 5.70 & 0.462 & 146.15 & 33.00 & 0.284 & 128.40 \\
\hline & 3 & 2011 & -10.29 & -0.092 & 82.25 & -88.80 & -0.103 & 101.49 & 8.80 & 0.544 & 225.64 & 44.70 & 0.355 & 173.93 \\
\hline & 4 & 2012 & -4.23 & -0.589 & 33.84 & -115.90 & 0.305 & 132.46 & 14.50 & 0.648 & 371.79 & 55.30 & 0.237 & 215.18 \\
\hline & 5 & 2013 & -2.20 & -0.480 & 17.60 & -130.40 & 0.125 & 149.03 & 18.50 & 0.276 & 474.36 & 58.30 & 0.054 & 226.85 \\
\hline \multirow{5}{*}{ ES } & 1 & 2011 & -3.30 & . & 100.00 & -91.90 & . & 100.00 & 8.90 & . & 100.00 & 46.20 & . & 100.00 \\
\hline & 2 & 2012 & -0.45 & -0.865 & 13.50 & -89.90 & -0.022 & 97.82 & 11.00 & 0.236 & 123.60 & 52.90 & 0.145 & 114.50 \\
\hline & 3 & 2013 & 1.46 & -4.278 & -44.26 & -95.20 & 0.059 & 103.59 & 13.00 & 0.182 & 146.07 & 55.50 & 0.049 & 120.13 \\
\hline & 4 & 2014 & 1.00 & -0.318 & -30.20 & -97.80 & 0.027 & 106.42 & 12.90 & -0.008 & 144.94 & 53.20 & -0.041 & 115.15 \\
\hline & 5 & 2015 & 1.02 & 0.020 & -30.80 & -89.70 & -0.083 & 97.61 & 11.40 & -0.116 & 128.09 & 48.30 & -0.092 & 104.55 \\
\hline \multirow{5}{*}{ IE } & 1 & 2009 & -4.67 & . & 100.00 & -116.50 & . & 100.00 & 3.60 & . & 100.00 & 24.80 & . & 100.00 \\
\hline & 2 & 2010 & -1.21 & -0.741 & 25.86 & -114.60 & -0.016 & 98.37 & 6.90 & 0.917 & 191.67 & 28.40 & 0.145 & 114.52 \\
\hline & 3 & 2011 & -1.65 & 0.367 & 35.35 & -139.20 & 0.215 & 119.48 & 8.80 & 0.275 & 244.44 & 29.90 & 0.053 & 120.56 \\
\hline & 4 & 2012 & -2.63 & 0.593 & 56.33 & -137.40 & -0.013 & 117.94 & 9.20 & 0.045 & 255.56 & 31.10 & 0.040 & 125.40 \\
\hline & 5 & 2013 & 2.13 & -1.809 & -45.59 & -131.60 & -0.042 & 112.96 & 8.00 & -0.130 & 222.22 & 27.00 & -0.132 & 108.87 \\
\hline \multirow{5}{*}{ PT } & 1 & 2010 & -10.31 & . & 100.00 & -104.30 & . & 100.00 & 5.70 & . & 100.00 & 28.20 & . & 100.00 \\
\hline & 2 & 2011 & -5.46 & -0.471 & 52.94 & -100.70 & -0.035 & 96.55 & 6.20 & 0.088 & 108.77 & 30.20 & 0.071 & 107.09 \\
\hline & 3 & 2012 & -2.02 & -0.630 & 19.60 & -116.50 & 0.157 & 111.70 & 7.70 & 0.242 & 135.09 & 38.00 & 0.258 & 134.75 \\
\hline & 4 & 2013 & 0.73 & -1.364 & -7.13 & -116.30 & -0.002 & 111.51 & 9.30 & 0.208 & 163.16 & 38.10 & 0.003 & 135.11 \\
\hline & 5 & 2014 & -0.25 & -1.345 & 2.46 & -118.60 & 0.020 & 113.71 & 8.40 & -0.097 & 147.37 & 34.70 & -0.089 & 123.05 \\
\hline
\end{tabular}

Source: Authors' calculations with data from AMECO and Eurostat 
The European crisis: Analysis of the macroeconomic imbalances in the rescued euro...

Table A.3

Indices of internal imbalances

\begin{tabular}{|c|c|c|c|c|c|c|c|c|c|c|c|c|c|c|}
\hline \multirow[b]{3}{*}{ Country } & \multirow[b]{3}{*}{ Year $\mathrm{t}$} & \multirow{3}{*}{ Year } & \multicolumn{12}{|c|}{ Internal imbalances } \\
\hline & & & \multicolumn{3}{|c|}{ Real GDP } & \multicolumn{3}{|c|}{ Unemployment rate } & \multicolumn{3}{|c|}{ Public debt } & \multicolumn{3}{|c|}{ Private sector debt } \\
\hline & & & $\begin{array}{l}\text { Mrd } \\
\text { EUR }\end{array}$ & $\begin{array}{l}\text { Annual } \\
\text { growth } \\
\text { rate }\end{array}$ & Index & \begin{tabular}{c|}
$\%$ of \\
active \\
population
\end{tabular} & $\begin{array}{l}\text { Annual } \\
\text { growth } \\
\text { rate }\end{array}$ & Index & $\begin{array}{l}\% \text { of } \\
\text { GDP }\end{array}$ & $\begin{array}{l}\text { Annual } \\
\text { growth } \\
\text { rate }\end{array}$ & Index & $\begin{array}{l}\% \text { of } \\
\text { GDP }\end{array}$ & $\begin{array}{l}\text { Annual } \\
\text { growth } \\
\text { rate }\end{array}$ & Index \\
\hline \multirow{5}{*}{$\mathrm{CY}$} & 1 & 2012 & 18.77 & . & 100.00 & 11.90 & . & 100.00 & 79.67 & . & 100.00 & 328.10 & . & 100.00 \\
\hline & 2 & 2013 & 17.66 & -0.059 & 94.07 & 15.90 & 0.336 & 133.61 & 102.61 & 0.288 & 128.80 & 340.10 & 0.037 & 103.66 \\
\hline & 3 & 2014 & 17.41 & -0.014 & 92.75 & 16.10 & 0.013 & 135.29 & 107.48 & 0.047 & 134.91 & 352.50 & 0.036 & 107.44 \\
\hline & 4 & 2015 & 17.75 & 0.020 & 94.58 & 15.00 & -0.068 & 126.05 & 107.50 & 0.000 & 134.94 & 353.50 & 0.003 & 107.74 \\
\hline & 5 & 2016 & 18.36 & 0.034 & 97.79 & 13.00 & -0.133 & 109.24 & 106.58 & -0.009 & 133.78 & 342.80 & -0.030 & 104.48 \\
\hline \multirow{5}{*}{ EL } & 1 & 2009 & 239.13 & . & 100.00 & 9.60 & . & 100.00 & 126.74 & . & 100.00 & 116.50 & . & 100.00 \\
\hline & 2 & 2010 & 226.03 & -0.055 & 94.52 & 12.70 & 0.323 & 132.29 & 146.25 & 0.154 & 115.39 & 128.10 & 0.100 & 109.96 \\
\hline & 3 & 2011 & 205.39 & -0.091 & 85.89 & 17.90 & 0.409 & 186.46 & 172.07 & 0.177 & 135.76 & 130.20 & 0.016 & 111.76 \\
\hline & 4 & 2012 & 190.39 & -0.073 & 79.62 & 24.50 & 0.369 & 255.21 & 159.56 & -0.073 & 125.89 & 131.50 & 0.010 & 112.88 \\
\hline & 5 & 2013 & 184.22 & -0.032 & 77.04 & 27.50 & 0.122 & 286.46 & 177.41 & 0.112 & 139.97 & 129.10 & -0.018 & 110.82 \\
\hline \multirow{5}{*}{ ES } & 1 & 2011 & 1070.14 & . & 100.00 & 21.40 & . & 100.00 & 69.53 & . & 100.00 & 196.40 & . & 100.00 \\
\hline & 2 & 2012 & 1038.81 & -0.029 & 97.07 & 24.80 & 0.159 & 115.89 & 85.74 & 0.233 & 123.30 & 188.00 & -0.043 & 95.72 \\
\hline & 3 & 2013 & 1021.09 & -0.017 & 95.42 & 26.10 & 0.052 & 121.96 & 95.45 & 0.113 & 137.27 & 177.20 & -0.057 & 90.22 \\
\hline & 4 & 2014 & 1035.18 & 0.014 & 96.73 & 24.50 & -0.061 & 114.49 & 100.37 & 0.052 & 144.34 & 165.80 & -0.064 & 84.42 \\
\hline & 5 & 2015 & 1070.71 & 0.034 & 100.05 & 22.10 & -0.098 & 103.27 & 99.44 & -0.009 & 143.01 & 155.20 & -0.064 & 79.02 \\
\hline \multirow{5}{*}{ IE } & 1 & 2009 & 164.62 & . & 100.00 & 12.70 & . & 100.00 & 61.54 & . & 100.00 & 256.10 & . & 100.00 \\
\hline & 2 & 2010 & 167.58 & 0.018 & 101.80 & 14.60 & 0.150 & 114.96 & 86.06 & 0.398 & 139.84 & 257.20 & 0.004 & 100.43 \\
\hline & 3 & 2011 & 172.59 & 0.030 & 104.84 & 15.40 & 0.055 & 121.26 & 110.34 & 0.282 & 179.29 & 272.70 & 0.060 & 106.48 \\
\hline & 4 & 2012 & 172.65 & 0.000 & 104.88 & 15.50 & 0.006 & 122.05 & 119.63 & 0.084 & 194.37 & 279.10 & 0.023 & 108.98 \\
\hline & 5 & 2013 & 175.48 & 0.016 & 106.60 & 13.80 & -0.110 & 108.66 & 119.43 & -0.002 & 194.06 & 267.10 & -0.043 & 104.30 \\
\hline \multirow{5}{*}{ PT } & 1 & 2010 & 179.93 & . & 100.00 & 12.00 & . & 100.00 & 96.18 & . & 100.00 & 201.50 & . & 100.00 \\
\hline & 2 & 2011 & 176.64 & -0.018 & 98.17 & 12.90 & 0.075 & 107.50 & 111.39 & 0.158 & 115.81 & 204.10 & 0.013 & 101.29 \\
\hline & 3 & 2012 & 169.53 & -0.040 & 94.22 & 15.80 & 0.225 & 131.67 & 126.22 & 0.133 & 131.23 & 210.30 & 0.030 & 104.37 \\
\hline & 4 & 2013 & 167.61 & -0.011 & 93.15 & 16.40 & 0.038 & 136.67 & 129.04 & 0.022 & 134.16 & 202.40 & -0.038 & 100.45 \\
\hline & 5 & 2014 & 169.11 & 0.009 & 93.99 & 14.10 & -0.140 & 117.50 & 130.60 & 0.012 & 135.78 & 190.50 & -0.059 & 94.54 \\
\hline
\end{tabular}

Source: Authors' calculations with data from AMECO and Eurostat 

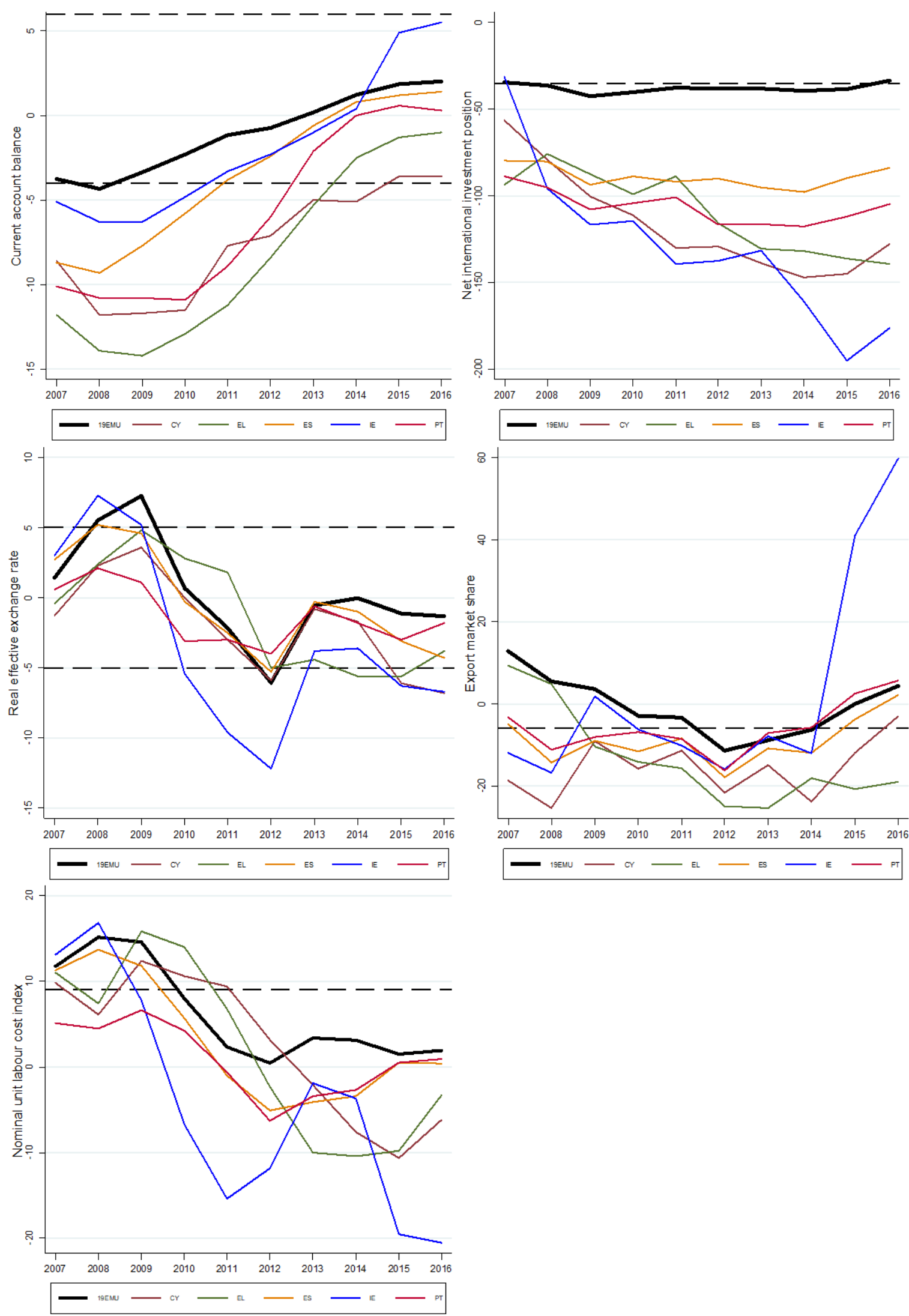

Figure A.1. External imbalances and competitiveness, 2007-2016 Source: Authors' calculations with data from Eurostat

Note: The variables are measured as in the MIP scoreboard (see Table 2) 


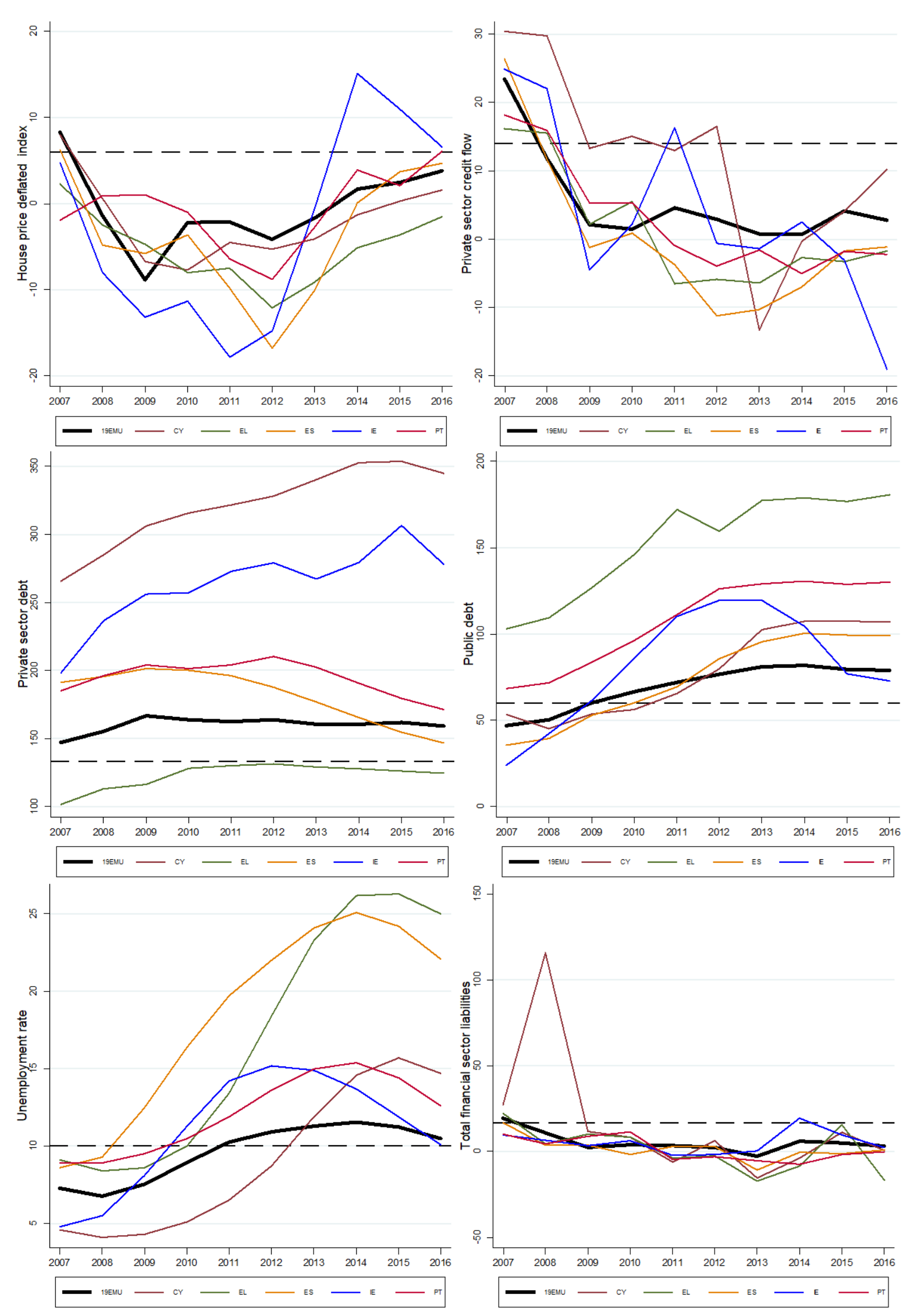

Figure A.2. Internal imbalances, 2007-2016

Source: Authors' calculations with data from Eurostat

Note: The variables are measured as in the MIP scoreboard (see Table 2) 

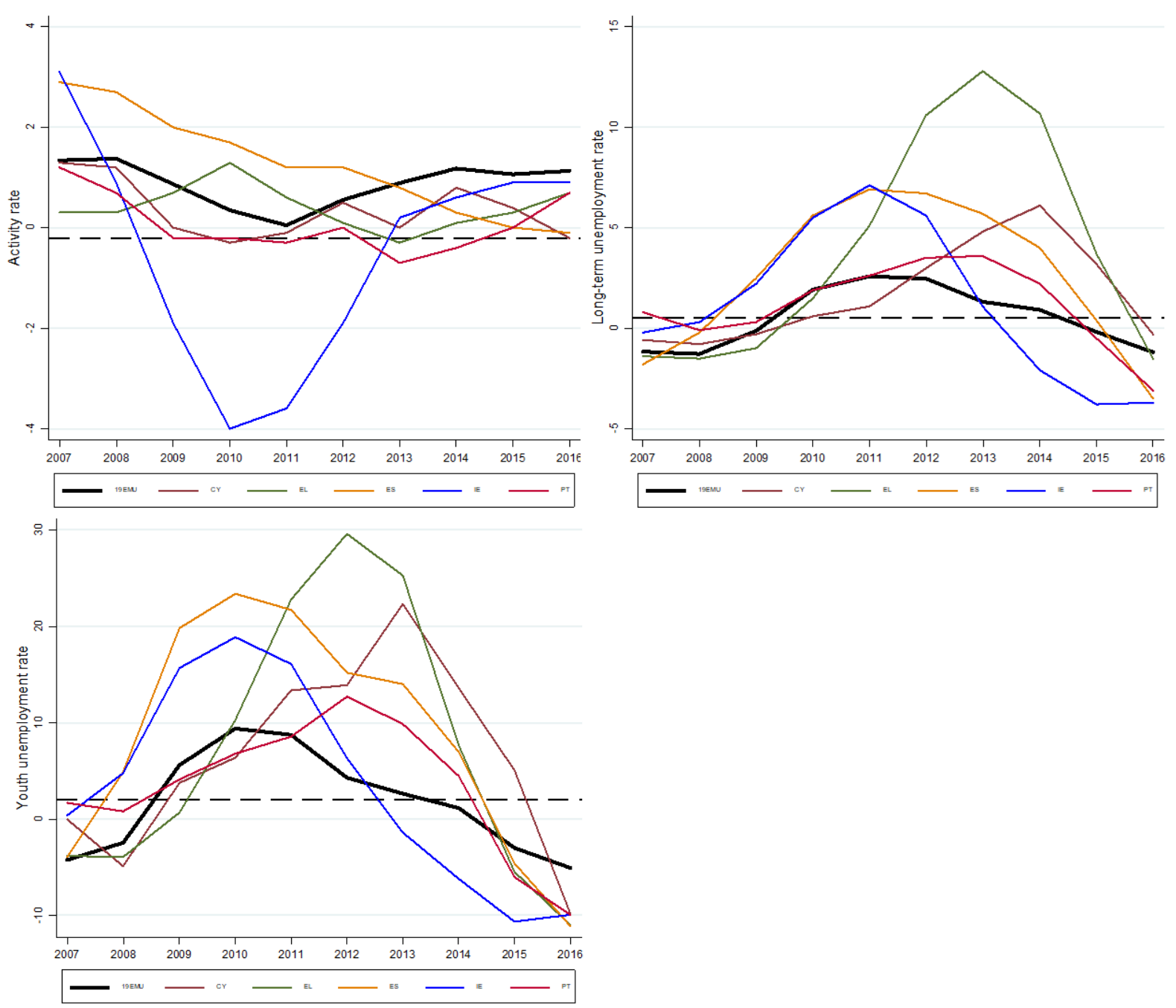

Figure A.3. Employment indicators, 2007-2016

Source: Authors' calculations with data from Eurostat

Note: The variables are measured as in the MIP scoreboard (see Table 2) 
Table A.4

Average of the headline indicators in EA and in rescued countries, 2007-2016

\begin{tabular}{|c|c|c|c|c|c|c|c|c|c|c|}
\hline Areas & Variable & $\begin{array}{c}\text { Upper } \\
\text { threshold }\end{array}$ & $\begin{array}{c}\text { Lower } \\
\text { threshold }\end{array}$ & Observ. & 19EA & CY & EL & ES & IE & PT \\
\hline \multirow{5}{*}{$\begin{array}{c}\text { External } \\
\text { imbalances and } \\
\text { competitiveness }\end{array}$} & $\begin{array}{l}\text { Current account } \\
\text { balance }\end{array}$ & $6 \%$ & $-4 \%$ & 10 & -1.0 & -7.6 & -8.3 & -3.5 & -1.8 & -5.9 \\
\hline & $\begin{array}{c}\text { Net international } \\
\text { investment position }\end{array}$ & & $-35 \%$ & 10 & -37.9 & -116.5 & -109.8 & -89.0 & -129.9 & -106.4 \\
\hline & $\begin{array}{l}\text { Real effective } \\
\text { exchange rate }\end{array}$ & $5 \%$ & $-5 \%$ & 10 & 0.4 & -2.0 & -1.3 & -0.4 & -3.2 & -1.4 \\
\hline & $\begin{array}{l}\text { Export market } \\
\text { share }\end{array}$ & & $-6 \%$ & 10 & -0.6 & -15.6 & -13.4 & -9.0 & 2.2 & -5.9 \\
\hline & $\begin{array}{l}\text { Nominal unit labour } \\
\text { cost index }\end{array}$ & $9 \%$ & & 10 & 6.2 & 2.5 & 1.9 & 3.0 & -4.2 & 0.9 \\
\hline \multirow{6}{*}{$\begin{array}{l}\text { Internal } \\
\text { imbalances }\end{array}$} & $\begin{array}{c}\text { House price index, } \\
\text { deflated }\end{array}$ & $6 \%$ & & 10 & -0.4 & -1.9 & -5.2 & -3.6 & -2.8 & -0.7 \\
\hline & $\begin{array}{l}\text { Private sector credit } \\
\text { flow, consolidated }\end{array}$ & $14 \%$ & & 10 & 5.5 & 11.9 & 1.3 & 0.3 & 3.9 & 2.9 \\
\hline & $\begin{array}{c}\text { Private sector debt, } \\
\text { consolidated }\end{array}$ & $133 \%$ & & 10 & 160.1 & 321.3 & 122.9 & 181.7 & 263.1 & 194.6 \\
\hline & $\begin{array}{c}\text { General } \\
\text { government gross } \\
\text { debt, EDP concept }\end{array}$ & $60 \%$ & & 10 & 69.4 & 77.9 & 153.1 & 73.8 & 81.7 & 107.6 \\
\hline & Unemployment rate & $10 \%$ & & 10 & 9.6 & 9.0 & 16.9 & 18.4 & 11.0 & 12.1 \\
\hline & $\begin{array}{c}\text { Total financial } \\
\text { sector liabilities, } \\
\text { non-consolidated }\end{array}$ & $16.5 \%$ & & 10 & 5.4 & 15.6 & 1.2 & 1.7 & 5.4 & 1.3 \\
\hline \multirow{3}{*}{$\begin{array}{l}\text { Employment } \\
\text { indicators }\end{array}$} & Activity rate & & -0.2 p.p. & 10 & 0.9 & 0.4 & 0.4 & 1.3 & -0.5 & 0.1 \\
\hline & $\begin{array}{c}\text { Long-term } \\
\text { unemployment rate }\end{array}$ & 0.5 p.p. & & 10 & 0.5 & 1.7 & 3.9 & 2.6 & 1.2 & 1.1 \\
\hline & $\begin{array}{c}\text { Youth } \\
\text { unemployment rate }\end{array}$ & 2 p.p. & & 10 & 1.7 & 6.4 & 7.2 & 8.6 & 3.4 & 3.3 \\
\hline
\end{tabular}

Source: Authors' calculations with data from Eurostat

Note: The variables are measured as in the MIP scoreboard (see Table 2) 